\title{
POTENTIAL ROLE \\ OF THE \\ FAST FLUX TEST FACILITY \\ AND THE \\ ADVANCED TEST REACTOR \\ IN THE \\ U.S. TRITIUM PRODUCTION SYSTEM
}

Policy Options White Paper

Office of Nuclear Energy, Science and Technology

U.S. Department of Energy

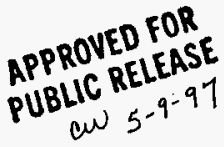

October 1996

DOES NOT CONTAIN CLASSIFIED OR

UNCLASSIFIED CONTROLLED

NUCLEAR INFORMATION

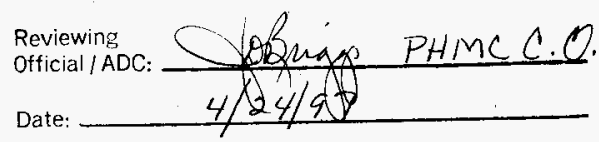


LEGAL. DISCLAIMER

This report was prepared as an account of work sponsored by an agency of the United States Government. Neither the

United States Government nor any agency thereof, nor any of their employees, nor any of their contractors, subcontractors or their employees, makes any warranty, express or implied. ot assumes any legal fiability or responsibility for the accuracy, completeness, or any third party's use or the resuits of such usa of any infomation, apparaus, product, or process diselosed, or represents that its use would not infringe privately owned rights. Reference herein to any specific commercial product, process, or service by trade name, trademak, manufacturer, or otherwise, does not necessarily constitute or imply its andorsement, recommendation, or favoring by the United States Government or any agency thereof or its contractors or subcontractors. The views and opinions of authors expressed herein do not necessarily state or reflect those of the United States Government or any agency thereot.

This report has been repraduced from the best avallable copy.

Printed in the United States of Amorien

DISCLM2.CHP (1-91)2 


\section{COKAEETE THIS SECTION REA A $4 L$ DO CUMENTS}

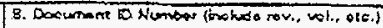

HNF-SP-1204, ReV. 0

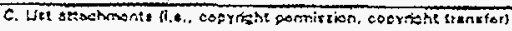

D. Dosunem Tide

Potential Role of the Fast Flux Test facility and the Aovanced Test Reactor Tritium in the U.S. Tritium Production Systen

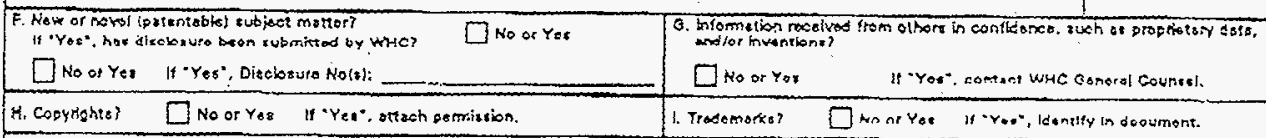

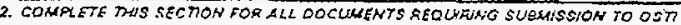

\begin{tabular}{|c|c|c|c|}
\hline A. Uneteststled Cotegory & $U C-$ & a. Butout s Roponting Codo & $B \& R-$ \\
\hline
\end{tabular}

A. Tuts of Loumel

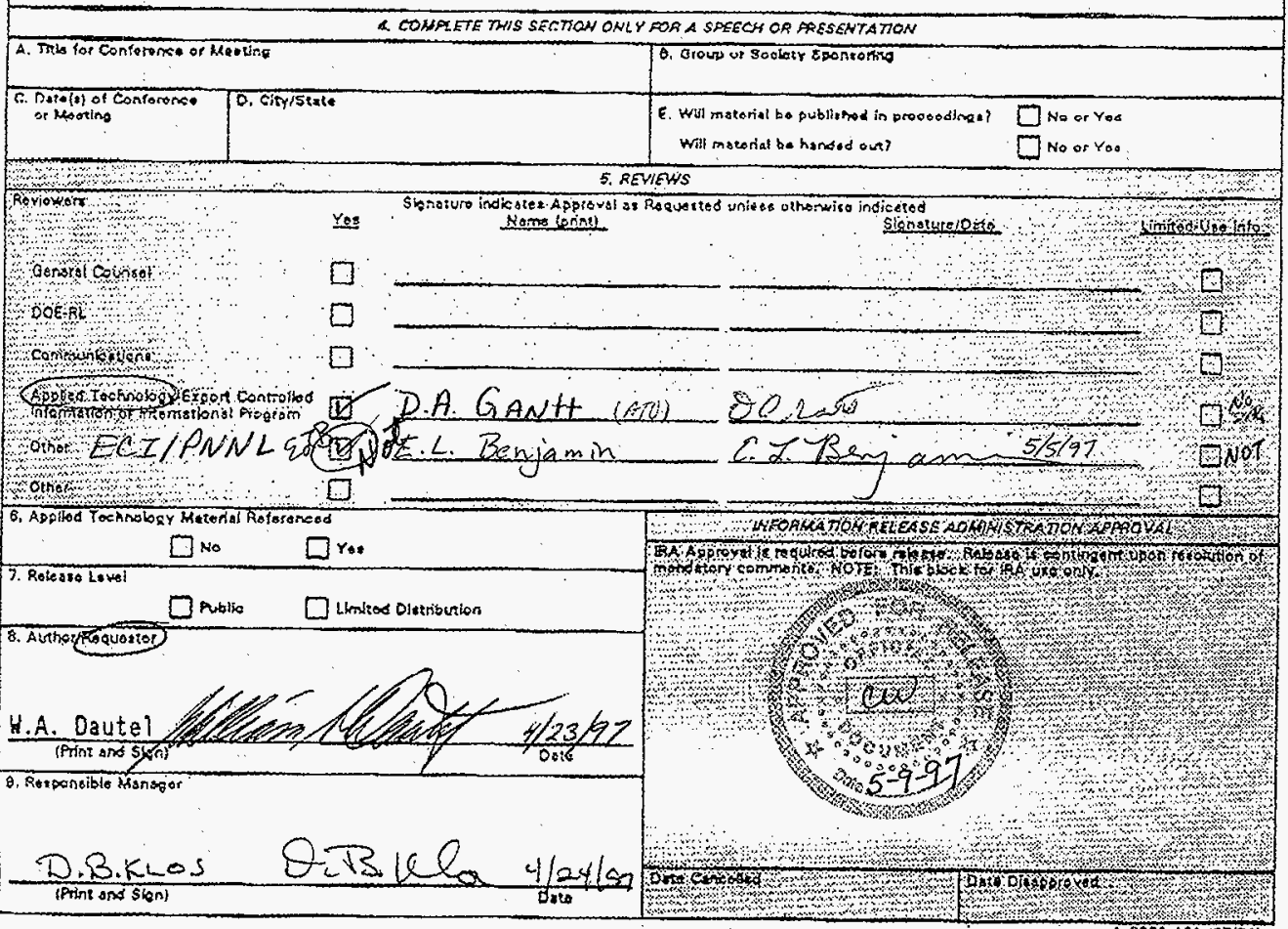


1. COMPLETE THIS SECTION FOR ALL DOCUMENTS

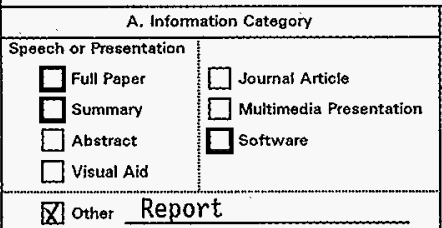

B. Document to Number (include rev., val., etc.)

HNF-SP-1204, Rev. 0

C. List attachments (i.e., copyright permission, copyright transfer)

\section{Document Titio}

Potential Role of the Fast Flux Test Facility and the Advanced Test Reactor Tritium

in the U.S. Tritium Production System

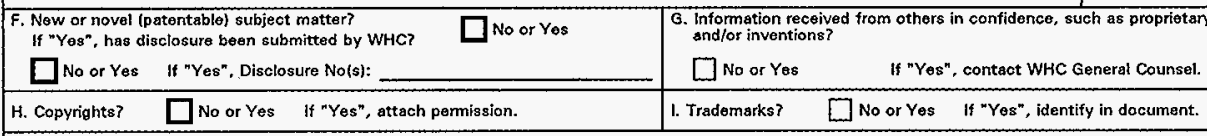

2. COMPLETE THIS SECTION FOR ALL DOCUMENTS REOUIRING SUBMISSION TO OSTI

\begin{tabular}{|l|l|}
\hline A. Unclassified Category $U C$ B. Budget \& Reporting Code BR - \\
\hline
\end{tabular}

3. COMPLETE THIS SECTION ONLY FOR A JOURNAL SUBMISSION

A. Titie of Journal

\section{COMPLETE THIS SECTION ONLY FOR A SPEECH OR PRESENTATION}

\begin{tabular}{|c|c|c|c|}
\hline \multicolumn{2}{|c|}{ A. Title for Conference or Meeting } & \multicolumn{2}{|l|}{ B. Group or Society Sponsoring } \\
\hline $\begin{array}{l}\text { C. Date(s) of Conference } \\
\text { or Meeting }\end{array}$ & D. City/State & $\begin{array}{l}\text { E. Will material be published in proceedings? } \\
\text { Will material be handed out? }\end{array}$ & $\begin{array}{l}\text { No or Yes } \\
\text { No or Yes }\end{array}$ \\
\hline
\end{tabular}

\section{0 rovarouser}

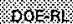

comouncontrons

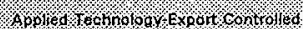
Yon fomation on finterational poorom

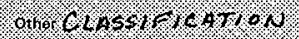

6tiber

6. Applied Technology Material Reforenced

$\square$ No $\square$ Yes

7. Release Level

$\square$ Public $\square$ Limited Distribution

8. Author/Requestor

W.A. Daute] (Print and Sign)

9. Responsible Manager 
HNF-SP-1204, Rev. 0 Document iD Number

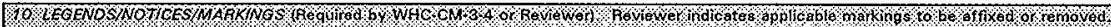

Affux Benove 1 rintials

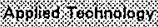

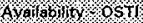

Avatabitit EsrsC

AvalaboivivNTis:

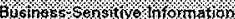

Computer Soltwaro Notion

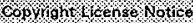

Export Cantrofled Intormation

Tegaro osctaine.

Unitiad 0180308 to

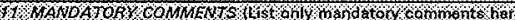

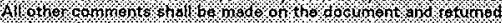
to the outron

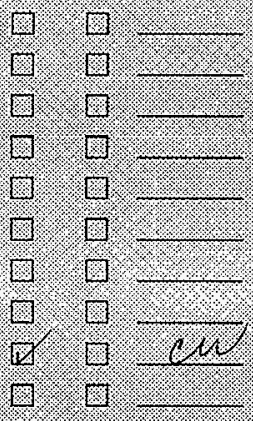

oftictos only

Potont statis

Prodectitionat information

Frograminotis Notico

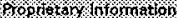

Purpose ond 0 so

Thesisto is seltation

Tradematk ois chat mot

othut
Aifix Kemove, initils

13.

15:

ㅊ.

닌. 12

11: $[1$

17.

[1]. 17

ㄴ.2.

1.1. 1

\% ADOLTONAL WNORNATIONTCOMMENTS?

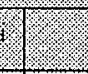

\begin{tabular}{|c|c|c|}
\hline retows ow & port & $\begin{array}{l}\text { Resolved by Author/Requestor } \\
\text { (Print \& Sign) }\end{array}$ \\
\hline
\end{tabular}




\section{POTENTIAL ROLE OF THE FAST FLUX TEST FACILITY AND THE ADVANCED TEST REACTOR IN THE U.S. TRITIUM PRODUCTION SYSTEM}

\section{SUMMARY}

The Department of Energy is currently engaged in a dual-track strategy to develop an accelerator and a commercial light water reactor (CLWR) as potential sources of tritium supply. New analysis of the production capabilities of the Fast Flux Test Facility (FFTF) at the Hanford Site argues for considering its inclusion in the tritium supply system.

The use of the FFTF (alone or together with the Advanced Test Reactor [ATR] at the Idaho National Engineering Laboratory) as an integral part of a tritium production system would help (1) ensure supply by 2005 , (2) provide additional time to resolve institutional and technical issues associated with the dual-track strategy, and (3) reduce discounted total life-cycle costs and near-term annual expenditures for accelerator-based systems. The FFTF would also provide a way to get an early start on dispositioning surplus weapons-usable plutonium as well as provide a source of medical isotopes.

\section{Challenges Associated With the Dual-Track Strategy}

The Department's purchase of either a commercial reactor of reactor irradiation services faces challenging institutional issues associated with converting civilian reactors to defense uses. In addition, while the technical capabilities of the individual components of the accelerator have been proven, the entire system needs to be demonstrated and scaled upward to ensure that the components work together as a complete production system. These challenges create uncertainty over the ability of the dual-track strategy to provide an assured tritium supply source by 2005 . Because the earliest the accelerator could come on line is 2007 , it would have to operate at maximum capacity for the first few years to regenerate the reserves lost through radioactive decay after 2005 .

\begin{tabular}{|l|}
\hline Production Uncertainties \\
- No U.S. tritium production source currently exists. \\
- Technical uncertainties may impact accelerator tritium production. \\
Institutional uncertainties may delay or prevent use of civilian reactors to produce tritium. \\
Iiming Uncerainties \\
- Tritium supply needs and associated dates are likely to change. \\
The current dual-track strategy lacks near-term production flexibility.
\end{tabular}

\section{Tritium Production in the FFTF and the ATR}

The FFTF and ATR could ensure tritium production in the near term, eliminating the need to draw down tritium reserves and to operate the accelerator at maximum capacity. 
The FFTF could be restared as early as the year 2000 at a production level of $1 \mathrm{~kg} / \mathrm{yr}$ of tritium and could ramp up to a production rate of at least $1.5 \mathrm{~kg} / \mathrm{yr}$ of tritium. (Based on reactor physics analyses. a próduction rate of about $2 \mathrm{~kg} / \mathrm{yr}$ may be possible.) The ATR could begin producing tritium by 1999 at a rate of $0.2 \mathrm{~kg} / \mathrm{yr}$ and could produce more than $0.3 \mathrm{~kg} / \mathrm{yr}$ by the year 2000 . If needed, the FFTF could produce tritium for a minimum of 20 years, and would probably be able to do so for a total of 30 yeats.

As shown in Table S-1, use of the FFTF and ATR could provide at least 10 years (beyond 2005) of additional time to develop a new tritium source. Even if the FFTF did not start up until 2002, use of the FFTF together with the ATR provides at least 8 additional years beyond 2005 for a new tritium source to come on line.

\begin{tabular}{|l|c|}
\hline \multicolumn{2}{|c|}{ Table S-1. Delay in the Required Start Date for a New Tritium Source } \\
(Accelerator or CLWR)
\end{tabular}

If the maximum FFTF production level (about $2 \mathrm{~kg} / \mathrm{yr}$ ) could be reached, the need for a new tritium source would be pushed far enough into the future that updated analyses would be conducted to determine whether another source would still be needed, given the arms control treaties in place at that time.

\section{Advantages of Delaying the New Tritium Source}

The additional time that the FFTF and ATR provide to bring on a new tritium source has three important benefits:

1. additional time to design, construct, and test an accelerator and bring it up to steady-state operation;

2. additional time to address institutional concerns associated with converting commercial reactors to defense use; and

3. a lower production level requirement for the accelerator, because it would not be required to regenerate reserves or maintain as high a steady state production rate. 


\section{Cost Advantages of Using the FFTF and the ATR}

Compared with the cursent dual-track development strategy, inclusion of the FFTF and the ATR in the tritum production system provides several important cost advantages. A system that included the FFTF and ATR would:

- provide more near-ferm tritium at a lower cumulative cost than the accelerator-only and purchased CLWR-only scenarios (see Table S-2);

- shift the large, near-term fuuding requirements for the accelerator or CLWR purchase options into the future, reducing neat-term expenditures;

- decrease life cycle costs for an accelerator-based tritium supply system; and

- reduce design, construction, and operating costs for the accelerator.

\begin{tabular}{|c|c|c|c|}
\hline $\begin{array}{c}\text { Scenario } \\
\text { (with approximate technology start dates) }\end{array}$ & $\begin{array}{l}\text { Cumulative Tritium } \\
\text { Production } \\
\text { (corrected for decay) }\end{array}$ & $\begin{array}{l}\text { Cumulative Cost } \\
\text { (undiscounted } 1996 \$ \text { in bill }\end{array}$ & \\
\hline Accelerator Only $(2007)$ & $8.8 \mathrm{~kg}$ & & 5.7 \\
\hline CLWR Onjy (2005) & $9.9 \mathrm{~kg}$ & $\begin{array}{l}\text { CLWR purchase: } \\
\text { Irradiation services: }\end{array}$ & $\begin{array}{l}2.5 \\
1.6\end{array}$ \\
\hline FFTF (2000)/New Source (2012) & $11.4 \mathrm{~kg}$ & $\begin{array}{l}\text { FFTF/Accelerator: } \\
\text { FFTF/CLWR purchase: } \\
\text { FFTF/nradiation services: }\end{array}$ & $\begin{array}{l}6.0 \\
1.9 \\
2.0\end{array}$ \\
\hline $\begin{array}{c}\text { FFTF }(2000) / A T R(1999) / \text { New Source }(2016) \\
\cdots\end{array}$ & $13.1 \mathrm{~kg}$ & $\begin{array}{l}\text { FFTF/ATR/Accelerator: } \\
\text { FFTF/ATR/CLWR purchase: } \\
\text { FFTF/ATR/rradiation services: }\end{array}$ & $\begin{array}{l}4.3 \\
2.0 \\
2.0\end{array}$ \\
\hline
\end{tabular}

In addition to the cost advantages, using the FFTF and ATR would also increase the reliability of tritium supply and the flexibility of the system to respond to changing requirements and conditions.

\section{Plutonium Disposition}

The FFTF could help the nation get an early start on dispositioning surplus weapons-usable plutonium. Use of the FFIF as part of the nation's tritium production system would provide a way to place over half of the high-purity surplus plutonium in irradiated fuel to achieve the "spent fuel standard." Using the FFTF for plutonium disposition and immobilizing the remainder of the surplus material could save about $\$ 440$ million compared with using all of the high purity plutonium in light water reactors and immobilizing the remainder. 


\section{Medical Isotope Production}

The FFTF could produce radioisotopes for medical use while producing $1.5 \mathrm{~kg} / y e a r$ of tritium. Above this level, there is a tradeoff between producing medical isotopes and increasing the tritium production rate. Operation at the $1.5 \mathrm{~kg} / \mathrm{yr}$ level would allow both missions to proceed concurrently. After a new tritium production source comes on line, the FFTF could revert to a medical isotope mission while providing backup and surge capacity for tritium production. Alternatively, the FFTF could coninue to produce both tritium and medical isotopes.

\section{Near-Term Activities and Costs}

A final decision on the technologies to be included in the nation's tritum supply system will be made in December 1998. To maintain the FFTF and ATR as options for inclusion in this system, supplements to the Final Programmatic Environmental Impact Statement for Tritium Supply and Recycling (PEIS) and its related Record of Decision (ROD) are needed for both reactors. In addition, to ensure that the FFTF, if selected as part of the tritium supply system, could start up in 2000 , work must begin in January 1997 to proceed with startup-related revisions to the facility's safety analysis report, design activities, and FFTF system restoration efforts. Safety analyses, target design and fabrication, and other activities must also be initiated at the ATR to ensure that it can begin producing tritium by 1999 .

These activities (including the PEIS and ROD supplements) for both the FFTF and the ATR could be completed at a total cost of about $\$ 52$ million in FY97 (about $\$ 43$ million for the FFTF, about $\$ 7$ million for the ATR, and about $\$ 2$ million for the PEIS and ROD supplements) and about $\$ 97$ million in FY98 (about $\$ 90$ million for the FFTF, about $\$ 5$ million for the ATR, and about $\$ 2$ million for the PEIS and ROD supplements). If funding currently allocated for FFTF shutdown activities can be reprogrammed to maintain the FFTF as a tritium production option over the next two years, the net additional funding requirements to cover activities at both the FFTF and the ATR would be about $\$ 20$ million in FY97 and about $\$ 60$ million in FY98. 


\section{TABLE OF CONTENTS}

SUMMARY

1. TRITIUM SUPPLY PLANS AṄD CHALLENGES $\ldots \ldots \ldots \ldots \ldots \ldots \ldots$

The Dual-Track Strategy $\ldots \ldots \ldots \ldots \ldots \ldots \ldots \ldots \ldots \ldots \ldots \ldots$

The Tritium Supply Date $\ldots \ldots \ldots \ldots \ldots \ldots \ldots \ldots \ldots \ldots \ldots \ldots \ldots \ldots \ldots \ldots \ldots$

Challenges Associated With the Dual-Track Strategy $\ldots \ldots \ldots \ldots \ldots \ldots \ldots$

Potential Tritium Supply Issues: Summary $\ldots \ldots \ldots \ldots \ldots \ldots \ldots \ldots \ldots$

2. THE FFTF: A POTENTIAL OPTION FOR MEETING NEAR-TERM

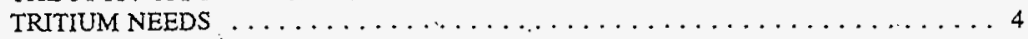

Potential Tritiurn Production Levels in the FFTF $\ldots \ldots \ldots \ldots \ldots \ldots \ldots \ldots 4$

Remaining FFTF Lifetime $\ldots \ldots \ldots \ldots \ldots \ldots \ldots \ldots \ldots \ldots$

Medical Isotope Production in the FFTF $\ldots \ldots \ldots \ldots \ldots \ldots \ldots \ldots \ldots$

Options for Integrating the FFTF into the Tritium Production System $\ldots \ldots \ldots \ldots$ s

Advantages of Including the FFTF in the Tritium Production System $\ldots \ldots \ldots \ldots 7$

3. DELAYING THE NEED FOR A NEW TRITIUM SOURCE $\ldots \ldots \ldots \ldots \ldots \ldots$.

Delay in the Need for a New Tritium Source: Summary $\ldots \ldots \ldots \ldots \ldots \ldots$

4. COST ADVANTAGES . . . . . . . . . . . . . . . .

Cost Advantages of an FFTF/ATR/Accelerator Tritium Supply System $\ldots \ldots \ldots \ldots 11$

Cost Advantages of an FFTF/ATR/CLWR Tritium Supply System $\ldots \ldots \ldots \ldots \ldots$

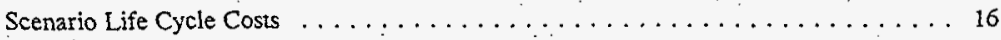

FFTF/ATR Cost Advantages: Summary $\ldots \ldots \ldots \ldots \ldots \ldots \ldots \ldots \ldots \ldots 17$

5. MITIGATING INSTITUTIONAL UNCERTAINTY $\ldots \ldots \ldots \ldots \ldots \ldots \ldots$

6. MATERIAL AND WASTE TRADEOFFS $\ldots \ldots \ldots \ldots \ldots \ldots \ldots \ldots \ldots \ldots \ldots \ldots \ldots \ldots \ldots$

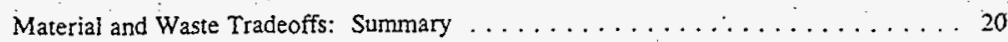




\section{HNF.SP-1204 \\ REV. $O$}

7. ACTIONS AND EXPENDITURES NEEDED TO MAINTAIN THE FFTF

AND THE ATR AS NEAR-TERM TRITIUM PRODUCTION OPTIONS

Neat-Term FFTF Costs $\ldots \ldots \ldots \ldots \ldots \ldots \ldots \ldots \ldots \ldots \ldots \ldots \ldots \ldots \ldots$

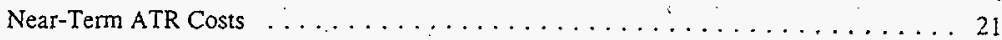

Total Near-Term Costs $\ldots \ldots \ldots \ldots \ldots \ldots \ldots \ldots \ldots \ldots \ldots \ldots \ldots$

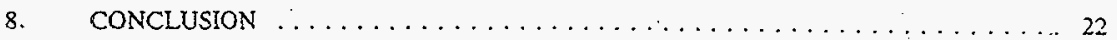

Sources of Conservatism in Assessing FFTF and ATR Advantages . . . . . . . 23 


\section{POTENTIAL ROLE OF THE FAST FLUX TEST FACILITY AND THE ADVANCED TEST REACTOR IN THE U.S. TRITIUM PRODUCTION SYSTEM}

Two potential tritium supply sources - an accelerator and a commercial light water reactor - are currently under development by the Department of Energy. New analysis of the effective operating life and production capabilities of the Fast Flux Test Facility (FFTF), located at the Hanford Site near Richland, Washington, argues in favor of formally including it as a component in developing a new tritium supply system. Using the FFTF as an integral part of a comprehensive tritium production system offers several key advantages over the current strategy and could help prevent a potentially serious tritium shortfall in the near term. In addition, using surplus weapons-usable plutonium in FFTF fuel provides a way to get an early start on dispositioning this material. A further benefit is that while producing tritium the FFTF could also produce medical isotopes.

This paper discusses the implications of introducing the FFTF as part of the tritium production system. The potential is assessed for the FFTF, alone and in concert with the Advanced Test Reactor (ATR) at Idaho National Engineering Laboratory, to ensure that tritium is produced rapidly, cost-effectively, and in an environmentally acceptable manner. The benefits of using the FFTF to achieve the "spent fuel standard"(1) for disposition of surplus weapons-usable plutonium are also evaluated: Finally, the activities and funding necessary to maintain the FFIF and the ATR as options through the funal selection of a new tritium source in December 1998 are desctibed. Details on the bases used for these assessments are provided in the Supplement to this paper.

\section{TRITIUM SUPPLY PLANS AND CHALLENGES}

Tritium is a fundamental component of U.S. nuclear weapons systems. Because radioactive decay reduces the amount of tritium by half every 12.3 years, tritium must be resupplied to maintain an adequate inventory for the nuclear weapons stockpile.

No active production capability for tritium is currently available to the Department of Energy. None of the nuclear reactors at DOE sites that produced tritium in the past is operational today, and no new tritium has been produced since 1988. The Deparment, therefore, is considering options for producing the needed tritium.

The Department completed its Final Programmatic Environmental Impact Statement for Tritium Supply and Recycling (PEIS) in October 1995(2) and issued a Record of Decision (ROD) in December 1995. ${ }^{(3)}$ The PEIS focused on two ways to supply the required tritium: (1) construct or purchase a new tritium supply facility large enough both to supply the tritium needed to offset natural decay and to provide a surge capacity above this level, and (2) constnuct or purchase a new facility that is large enough to supply the needed tritium and that could be quickly expanded, if needed, to provide surge capacity.

\footnotetext{
11) Achieving the "spent fuel standard" entails making the excess weapons plutonium as inaccessible and unattractive for use in weapons as is the plutonium in spent fuel from commercial nuclear power plants.

(2) DOE/EIS-016!.

13) 60 FR 238. pp. 63878-63891.
} 
Tritium production technologies that fulfilled these requirements were evaluated for assurance of supply, schedule, cost effectiveness, and environmental acceptability.

\section{The Dual-Track Strategy}

Based on its evaluation in the PEIS, the Department announced in the ROD that it would follow a dualtrack strategy for àcquiring new tritium production capability, under which it would

- initiate the purchase of either an existing commercial reactor (currently operating or unfinished) to produce tritium or irradiation services from one or more commercial reactors (with an option to purchase a reactor)

- design, build, and test critical components of an accelerator to produce tritium.

The Department currently intends to follow this dual-track strategy through December 1998, when it will select one of these sources to serve as the primary source of tritium. The other altemative, if proven feasible, will be developed as a back-up tritium source.

While the PEIS had rejected a potential third soutce of tritium - the FFTF - as part of the tritium production system, based primarily on its remaining operating life and inability to produce the full amount of tritium needed, the ROD nonetheless recognized that the FFTF was still under review as a tritium soutce. In fact, in the ROD, the Department committed to evaluate the FFTF to determine its potential role in meeting future tritium requirements. According to the $R O D$, if any changes to the ROD are warranted following the FFTF evaluation or if further documentation is required under the National Environmental Policy Act, the Department will take the appropriate action.

\section{The Trititim Supply Date}

The decision to pursue the dual-track strategy was based on a tritium reserve level that requires new tritium by 2011 [see point (b) on Figure 1]. However, current planning calls for a larger reserve stockpile, requiring new tritium by 2005 [see point (a) on Figure 1]. If new tritium is not supplied by 2005, the tritium reserves will fall below the targeted level; the new source must then both regenerate these reserves and supply enough tritium to maintain them. 
Figure 1: Tritium Slockpile with No Additions

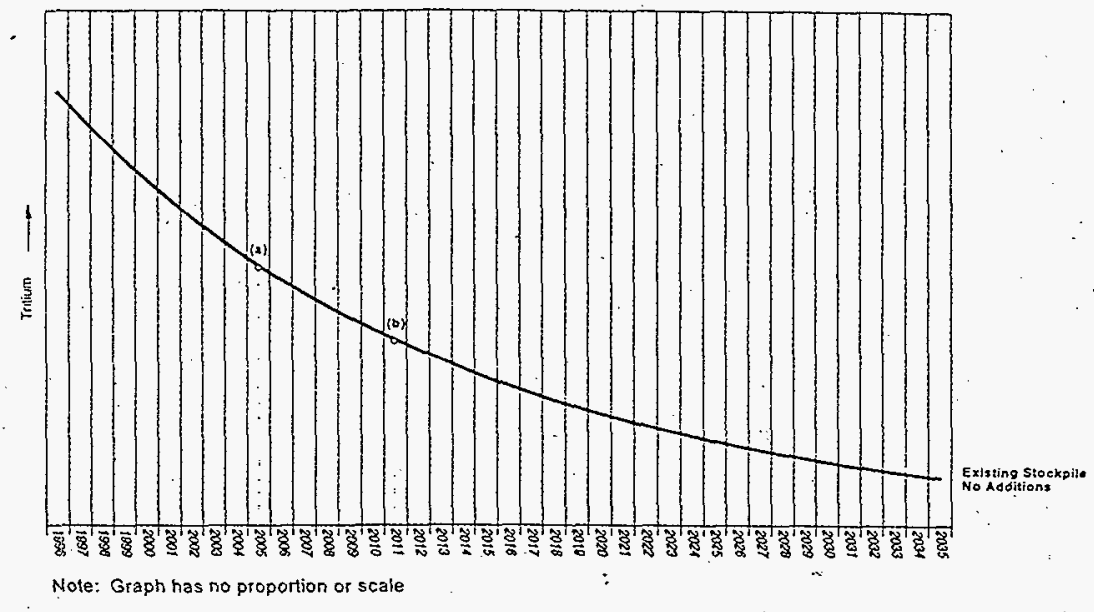

\section{Challenges Associated With the Dual-Track Strategy}

The commercial reactor and accelerator options face challenges that could result in potential shortfalls in the required tritium resupply. The challenges are characterized in the ROD as follows:

- DOE's purchase of either a commercial reactor or reactor irradiation services faces unresolved institutional issues associated with converting civilian reactors to defense uses.

- While the technical capabilities of the individual components of the accelerator have been proven, the entire system needs to be demonstrated [and scaled upward] to ensure that the components work together as a complete production system.

These challenges create significant uncertainty in the ability of the dual-track strategy to provide an assured tritium supply source in a timely manner. In particular, it is much less likely that the dual- . track strategy could provide new tritium by 2005 than by 2011. In fact, if the accelerator is selected as the primary tritium source, the earliest it could come on line would be $2007{ }^{(4)}$ which would necessitate drawing down the tritium reserves below the desired level. Any technical problems associated with scaling the accelerator up to the required size could delay the accelerator's completion beyond this date. Also, while high technical confidence exists that some commercial light water reactor (CLWR) options (in particular, purchasing irradiation services from a CLWR) could produce tritium by 2005 , institutional uncertainties facing conversion of civilian reactors to defense use could delay the CLWR contribution to the nation's tritium stockpiles beyond 2005 .

(4) This date results from compressing the planned accelerator construction schedule by two years. 
As the U.S. national defense strategy evolves, tritium supply requirements are likely to change; hence, the tritium supply system should exhibit schedule and production flexibility. Introducing the FFTF would provide both the requisite flexibility and increased certainty that near-term tritium supply objectives will be met.

\section{POTENTLAL TRITIUM SUPPLY ISSUES: SUMMARY}

\section{Production Uncertainties}

- No U.S. tritium production source currently exists.

- Technical uncertainties may impact accelerator tritium production.

- Instintional issues may delay or prevent use of civilian reactors to produce tritium.

\section{Timing Uncertainties}

- Tritium supply needs and associated dates are likely to change.

- The current dual-track strategy lacks near-term production flexibility.

\section{THE FFTF: A POTENTIAL OPTION FOR MEETING NEAR-TERM TRITIUM NEEDS}

The Final PEIS for Tritium Supply and Recyciing dismissed the FFTF from consideration based on the belief that (1) it could not produce the total amount of tritium needed, and (2) its remaining life would be insufficient to produce tritium over the total required time frame ( 40 years). However, new analysis shows that the FFTF should be inclided as a key element of the proposed tritium production system. In fact, several altemative tritium production systems that include the FFTF could meet the nation's tritium needs, resulting in several cost and instizutional advantages. Using the FFTF also offers ancillary benefits such as disposition of surplus weapons-usable plutonium and production of medical isotopes.

This section and subsequent sections describe these FFTF advantages and identify the actions that could be taken over the next two years to retain the FFTF as an option while still proceeding with the accelerator and CLWR alternatives. These actions are identical to those needed to testart the FFTF by 2000; going forward with these actions ensures that. if the Deparment's final tritium production decision (scheduled for December 1998) includes the FFTF, it could be restarted at the earliest possible time.

\section{Potential Tritium Production Levels in the FFTF}

The FFTF can produce significant amounts of tritium in the near term. The FFTF, which had an excellent operational performance tecord from 1982 10 1992 , could be restarted as early as the year 2000 at a production level of $1 \mathrm{~kg} / \mathrm{yr}$ of tritium and could ramp up to a production rate of at least 1.5 
$\mathrm{kg} / \mathrm{yr}$ of tritium. ${ }^{(3),(6)}$ While there is some uncenainty regarding the maximum production level that the FFTF could achieve, reactor physics analyses have estimated the potential production at 2 to $2.2 \mathrm{~kg} / \mathrm{yr}$. Because these higher production rates involve more highly enriched fuel and a more advanced target design than would be required to produce $1.5 \mathrm{~kg} / \mathrm{yr}$ of tritium, additional analysis and testing are needed to determine whether the calculated higher production levels could be realized in practice.

Using the FFTF provides high confidence that tritium requirements for the year 2005 could be met. The most aggressive scenario discussed in this paper assumes that the FFTF restarts in 2000 and ramps up to a production level of $1.5 \mathrm{~kg} / \mathrm{yr}$ by 2003 . The least aggressive of the scenarios discussed assumes that the FFTF restars in 2002 , producing $1 \mathrm{~kg} / \mathrm{yr}$ of tritium, and ramps up to a $1.5 \mathrm{~kg} / \mathrm{yr}$ production level by 2005 . Even under the slower schedule, the FFTF's contribution to the tritium production system would be significant and worthwhile.

\section{Remaining FFTF Lifetime}

Recent studies based on the FFTF's previous operation as a test reactor have demonstrated that the FFIF could operate for more than 20 years after restarting. However, because the neutron flux damage to key reactor components over these 20 years would be lower in the tritium production mode of operation than in the test mode, the effective remaining life would probably be at least 30 years. ${ }^{m}$

\section{Medical Isotope Production in the FFTF}

The FFTF could also produce radioisotopes for medical use while producing $1.5 \mathrm{~kg} / \mathrm{yr}$ of tritium. ${ }^{(8)}$ Above this level, there is a tradeoff between producing medical isotopes and increasing the tritium production rate. Operation at the $1.5 \mathrm{~kg} / \mathrm{yr}$ level would allow both missions to proceed concurrently.

\section{Options for Integrating the FFTF into the Tritium Production System}

The FFTF could be used alone or in combination with the Advanced Test Reactor (ATR) at the Idaho National Engineering Laboratory both to provide for near-term tritium needs and to delay the need to bring a new production source (an accelerator or a CLWR) on line. The advantages of using the FFTF. as part of the nation's tritium production system are amplified when it is paired with the ATR, which provides materials and fuels testing for the Naval Reactors program and produces radioisotopes for medical and other applications. The ATR could begin producing tritium by 1999 at a rate of $0.2 \mathrm{~kg} / \mathrm{yr}$ and could produce more than $0.3 \mathrm{~kg} / \mathrm{yr}$ by the year 2000 , providing additional confidence that tritium stockpiles will be maintained at or above needed levels. ${ }^{(9)}$

(5)"Technical Assessment of Tritium Production Capability at the Fast Flux Test Facility." Repon prepared by the U.S. Deparment of Energy. Office of Nuclear Energy, Science and Technology, March 1996.

(6) "Technical Assessmens of Tritium Production Capability of the Fast Flux Test Facility." Report prepared by the U.S. Department of Energy, Defense Programs Tritium Office, March 1996.

(7) -Tritium Production at the Fast Flux Test Facility." Draft report prepared for the U.S. Deparmeni of Energy by Westinghouse Hanford Corporation, January 1996.

(8) Examples of radioisotopes that might be produced for medical applications include Actinium-227 and Strontium-89.

(9) "Operating the Advanced Test Reactor to Support Naval Reactor Programs. Isotope Production, and Interim Tritium Production." Letter report prepared for the U.S. Deparment of Energy by Lockheed Martin Idaho Technologies. September 17. 1996. 
Several promising combinations of technologies (scenarios) that include the FFTF, alone or together with the ATR, are listed below. (Details on production dates and schedules are given in the text box; further details are provided in Part A of the Supplement to this paper.)

\section{Tritium Production. in the FFTF}

Technical studies show that the FFTF could

- restart as early as 2000 and begin producing tritium as a rate of $1 \mathrm{~kg} / \mathrm{yr}$

- ramp up to a tritium production rate of $1.5 \mathrm{~kg} / \mathrm{yr}$ beginning as early as 2003 .

Technical analyses also indicate that the FFTF could ramp up further and begin producing about $2 \mathrm{~kg} / \mathrm{yr}$ of tritium as early as 2005. However, for purposes of this analysis, a tritium production rate of $1.5 \mathrm{kghr}$ has been assumed.

Tests of the advanced fuel and targets needed for producing $1.5 \mathrm{~kg} / \mathrm{yr}$ and $2 \mathrm{~kg} / \mathrm{yr}$ of tritium would be conducted while producing tritium at lower levels (1 $\mathrm{kg} / \mathrm{yr}$ and $1.5 \mathrm{~kg} / \mathrm{yr}$, respectively).

Currently-available FFTF fuel - fresh and partially irradiated - would provide about 1.5 years of operarion. A new fuel supply, produced in the Fuel and Materials Examination Facility (FMEF) at the Hanford Site, would be needed after that time.

The FFTF fuel could use much of the nation's surplus weapors-usable plutonium, providing a way to get an early start on the plutonium disposition process. The FFIF also provides the opportunity to produce medical isotopes.

\section{Tritium Production in the ATR}

Technical studies show that the ATR could begin producing tritum by mid-1998 and could ramp up to its ultimate production rate by 2000 .

The ATR could, at maximum production, produce more than $0.3 \mathrm{~kg}$ of tritium per year without compromising the Naval Reactors mission of this facility. A $0.2 \mathrm{kghr}$ production rate could be achieved without modifying the facility's Safery Analysis Report. For purposes of this analysis, a production rate of $0.2 \mathrm{~kg} / \mathrm{yr}$ has been assumed.

(1) FFTF/Accelerator: The FFTF could be used to meet near-term tritium needs, allowing the accelerator to come on line several years later than is currently required. Operating the FFTF also would produce enough tritium to avoid the need to tap into the tritium reserves; therefore, the accelerator could be sized and operated at a lower production level than would be required to replenish the reserves. After the accelerator comes on line, both technologies could operate at moderate production rates to maintain the tritium stockpile; alternatively, the accelerator could be operated at a higher production level and the FFTF could provide backup and surge capacity (while producing medical isotopes).

(2) FFTF/ATR/Accelerator: The FFTF could be used along with the ATR to further delay the time at which a new accelerator must come on line. The ATR would cease its tritium production mission after the accelerator comes on line, but could provide backup and surge capacity. Borth the FFTF and the accelerator could operate at moderate production rates to maintain the tritium 
stockpile; alternatively, the acceletator could be operated at a higher production level and the FFTF could provide backup and surge capacity (while producing medical isotopes).

(3) FFTE/CLWR: The FFTF could be used to meet near-term tritium needs, allowing the CLWR (a purchased reactor or purchased irradiation services) to come on line later than is currently required. Both technologies could operate at moderate production rates to maintain the tritium stockpile; altematively, the CLWR could be operated at a higher production level and the FFTF could provide backup and surge capacity (while producing medical isotopes) after the CLWR comes on line.

(4) FFTE/ATR/CLWR: The FFTF could be used along with the ATR to further delay the time at which a CLWR (a purchased reactor or purchased irradiation services) must come on line. The ATR would cease its tritium production mission after the CLWR comes on line, but could provide backup and surge capacity. The FFTF and CLWR could operate at moderate production rates to maintain the tritium stockpile; alternatively, the CLWR could be operated at a higher production level and the FFTF could provide backup and surge capacity (while producing medical isotopes).

These alternatives are compared with the two options included in the Department's December 1995 ROD:

(5) Accelerator only: The accelerator is chosen as the primary tritium production technology; a CLWR (a purchased reactor or purchased irradiation services) could serve as a backup tritium source.

The earliest the accelerator could come on line would be 2007 . The accelerator working alone would have to operate at its maximum designed production level for the first few years of operation to return the stockpile to, and maintain it at, the needed level. If a CLWR could begin operation before 2005 , it would ease the burden on the accelerator (and presumably would retum to backup status when the accelerator comes on line).

(6) CLWR only: A CLWR (a purchased reactor or purchased irradiation services) is chosen as the primary tritium production technology; the accelerator could serve as a backup tritium source. In the absence of instiutional delays, the CLWR is assumed to come on line in 2005.

\section{Advantages of Including the FFTF in the Tritium Production Systern .}

The FFTF provides significant advantages when used as part of an overall tritium production system: .

- The FFTF could both meet near-term tritium needs and delay the need for a new tritium source, leaving more time to evaluate, license, construct, and test potential new sources.

- The FFTF, as part of an overall tritium production system, offers cost advantages.

- The FFTF could mitigate institutional uncertainty associated with the two technologies included in the current dual-track strategy.

- The FFTF could perform ancillary missions, such as dispositioning surplus weapons-usable plutonium and producing medical isotopes.

Each of these advantages is discussed in a section below, drawing on the scenarios described above. 


\section{DELAYING THE NEED FOR A NEW TRITIUM SOURCE}

The impacis of the FFTF and the ATR on the nation's tritium reserves are shown in Figure 2. The graph shows the effects of the FFTF producing $1.5 \mathrm{~kg}$ of tritum per year and the ATR producing 0.2 $\mathrm{kg}$ per year on the need date for a new tritium source.

Using the FFTF alone beginning in 2000 delays the need for a new tritium source until about 2012 [see point (c) on the graph]. When used in conjunction with the ATR, the FFTF could delay the need for a new tritium source until about 2016 [point (d) on the graph]. [Points (a) and (b) indicate the new 2005 need date for new tritium and the previous 2011 need date.]

After a new tritium source (an accelerator or a CLWR) comes on line, the ATR would end its tritium production mission. The FFTF could continue to provide tritium after this time, providing diversity in tritium supply technologies and allowing the new source to operate at a lower level of production than if it were the sole tritium source. ${ }^{(10)}$ Alternatively, the FFTF could revert to a source of backup and . surge capacity while producing medical isotopes and converting surplus weapons-usable plutonium to the "spent fuel standard."

Figure 2: Trition Stockpile with FFTF and ATR Additions

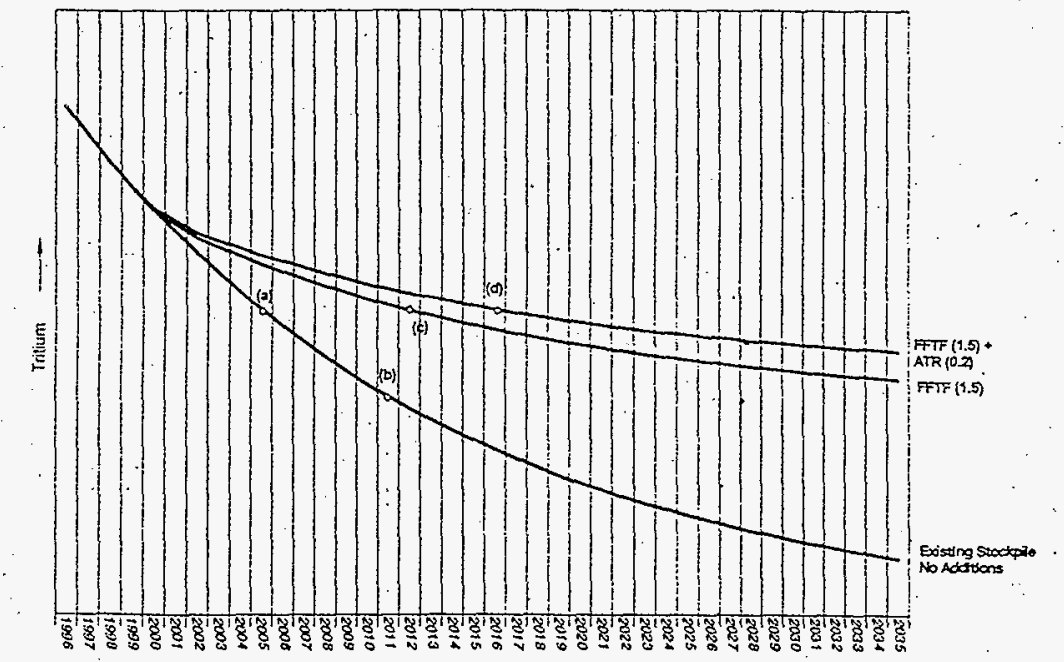

- Note: Graph has no proportion or scale

(10) The accelerator could be expanded to produce higher levels of tritium if necessary. The CLWR option provides the advantage of scale up or scale down to any foreseeable level. especially through purchase of irradiation services. 
Table 1 provides more detail on how the FFTF, used as part of a tritium production system, could meet near-term tritium needs and delay the need for a new tritium source.

\begin{tabular}{|c|c|}
\hline Table 1. Delay in the Required Start Date for a New Tritium Source \\
(Accelerator or CLWR)
\end{tabular}

As shown in Table 1, with the FFTF producing $1.5 \mathrm{~kg}$ of tritium per year and the ATR producing 0.2 $\mathrm{kg}$ per year, an additional tritium source would have at least 10 years (beyond 2005) for design. construction (if necessary), testing, and licensing. Even under a scenario in which the FFTF does not start up until 2002, using the FFTF together with the ATR provides the benefit of at least 8 years beyond 2005 for a new tritium source to come on line.

If the maximum FFTF production level (about $2 \mathrm{~kg} / \mathrm{yr}$ ) can be reached, the need for a new tritium source is pushed far enough into the future that, presumably, new analyses would be conducted to determine whether a new source is still needed given the arms control treaties in place at that time and other relevant factors. (In fact, the PEIS Executive Summary states, "If the need date for new tritium were significantly later than 2011, the Department would not have a proposal for new tritium supply, and would not be preparing a PEIS for Tritium Supply and Recycling. ${ }^{\text {(iii) }}$ )

An additional benefit of using the FFTF to provide tritium in the near term is that it would allow the new. source to be constructed for and operated at a lower tritium production level than would otherwise be the case, resulting in a reduced cost for the new source. In contrast, if the accelerator is used alone, beginning operation in 2007 , the tritium production rate would have to be near the maximum capacity for the first few years of operation to reestablish and maintain the desired tritium inventory.

(II) Page S-is. 


\section{. DELAY IN THE NEED FOR A NEW TRITIUM SOURCE: SUMMARY}

Operating the FFTF and ATR as part of the tritium production system will delay the need for a new tritium source. This additional time provides three benefits:

- additional time to design, construct, and test an accelerator and bring it up to steadystate operation

- additional time to address instiutional concems associated with converting commercial light water reactors to defense use

- a lower production level requirement for the new tritium source, which translates into a smaller and less expensive new facility that is not taxed to produce at its maximum capacity immediately upon startup.

\section{COST ADVANTAGES}

Compared with the current dual-track strategy, the schedule extensions for obtaining new sources made possible by the inclusion of the FFTF and the ATR in the tritium production system provide important cost advantages by

- shifting the large funding requirements for a new tritium source into the future, reducing nearterm funding requirements as well as (for accelerator-based systems) the total discounted lifecycle costs, and

- affording additional time to bring new technologies on line, which allows design and development costs to be spread over a longer period, decreasing peak expendinures. ${ }^{(122,(13)}$

This section evaluates the changes in expendiure patterns and total system cosis when the FFTF and ATR are used to supplement the operation of a new source. The specific dates by which a new source would come on line when supplemented by the FFTF and ATR depend on the specific operating assumptions associated with each facility. For computing representative cosis, the FFTF is assumed to come on line in 2000 and the ATR in 1999 . The following assumptions are made regarding the start dates for new sources:

- accelerator only: 2007

- ClWR only: 2005

- accelerator or CLWR when supplemented by the FFTF: 2012

- accelerator or CLWR when supplemented by the FFTF and the ATR: 2016.

" "12ischedule extensions allow new tritium sources to be designed for and operated at lower ritium production levels than would be feasible without the FFTF and ATR, resulting in additional cost savings. However, for this analysis the capital. costs of new sources are assumed the same regardless of required production levels. This is a conservative assumption that leads to a lower estimated cost advantage than would result if these savings were included in the analysis.

${ }^{113}$ Experience with' large, capital-intensive development and constriction projects indicates that schedule extensions may also provide absolute (nondiscounted) cost savings compared with rapid-track projects because of faciors such as decreased use of overnime work and fewer rapid change order requirements. However, such potential savings are not included in this analysis. 
The tritium produced by a facility is assumed to be available to the stockpile when it is produced. although in reality there is a delay between the production of tritium and its extraction and subsequent purification. (The accelerator may be operated so that there is no delay between tritium production and availability.)

\section{Cost Advantages of an FFTF/ATR/Accelerator Tritium Supply System}

The cost advantages of the schedule extension provided by the FFTF and ATR are particularly significant if the accelerator is selected as the future tritium supply source. Including the FFIF as part of an accelerator-based tritium supply system shifts peak funding requirements about four years into the furure and reduces peak expendiures by over $\$ 250$ million annually compared with the expenditures for the accelerator alone. Adding the ATR to a FFTF/accelerator tritium supply system shifts peak funding about ten years into the furure and reduces peak expendirures by an additional $\$ 70$ million annually.

Pan B of the Supplement to this paper provides the estimated cost profiles through 2035 for the three relevant scenarios: (1) the accelerator as the primary funre tritium source ("accelerator only"); (2) the FFTF as a near-term supplement to the accelerator ("FFTF/accelerator"); and (3) the FFTF and the ATR as near-term supplements to the accelerator ("FFIF/ATR/accelerator"). Figure 3 depicts estimated expenditure patterns for these three scenarios over the next decade. Expendinures for the accelerator-only option peak at almost $\$ 1$ billion annually in 2003 and 2004 . In comparison, the expenditures for the FFTF/accelerator option rise more slowly, reaching approximately $\$ 640$ million in 2006. Adding the ATR further reduces the near-term expenditure impacts, with annual expenditures rising to abour $\$ 340$ million by 2006 .

Near-term expenditures on the FFTF and the ATR provide significant amounts of new tritium compared with developing the accelerator. A tritium production system that includes the FFTF and the ATR is less expensive than the accelerator-only option and provides a significant near-term tritium production capability. A comparison of supply system costs and net new tritium production through 2011 is shown in Figure 4. Annual production capacities of $1.5 \mathrm{~kg}$ for the FFTF and $0.2 \mathrm{~kg}$ for the ATR are assumed. (Production of $2 \mathrm{~kg} / \mathrm{yr}$ and $0.3 \mathrm{~kg} / \mathrm{yr}$ in the FFTF and the ATR, respectively, would further enhance the cost and schedule benefits of these technologies.) The accelerator operating . costs are assumed to be higher when the accelerator is used alone than when it is supplemented by the FFTF alone or by a combination of the FFTF and ATR. ${ }^{(! d)}$

(14) The difference between the annual operating costs for the larger accelerator (in the "accelerator only" scenario) and the smaller accelerator (in the "FFTF/accelerator" and "FFTF/ATR/accelerator" scenarios) is assumed to be \$56 million: about $\$ 22$ million of this represents the difference in electricity cosis for the two accelesators. 

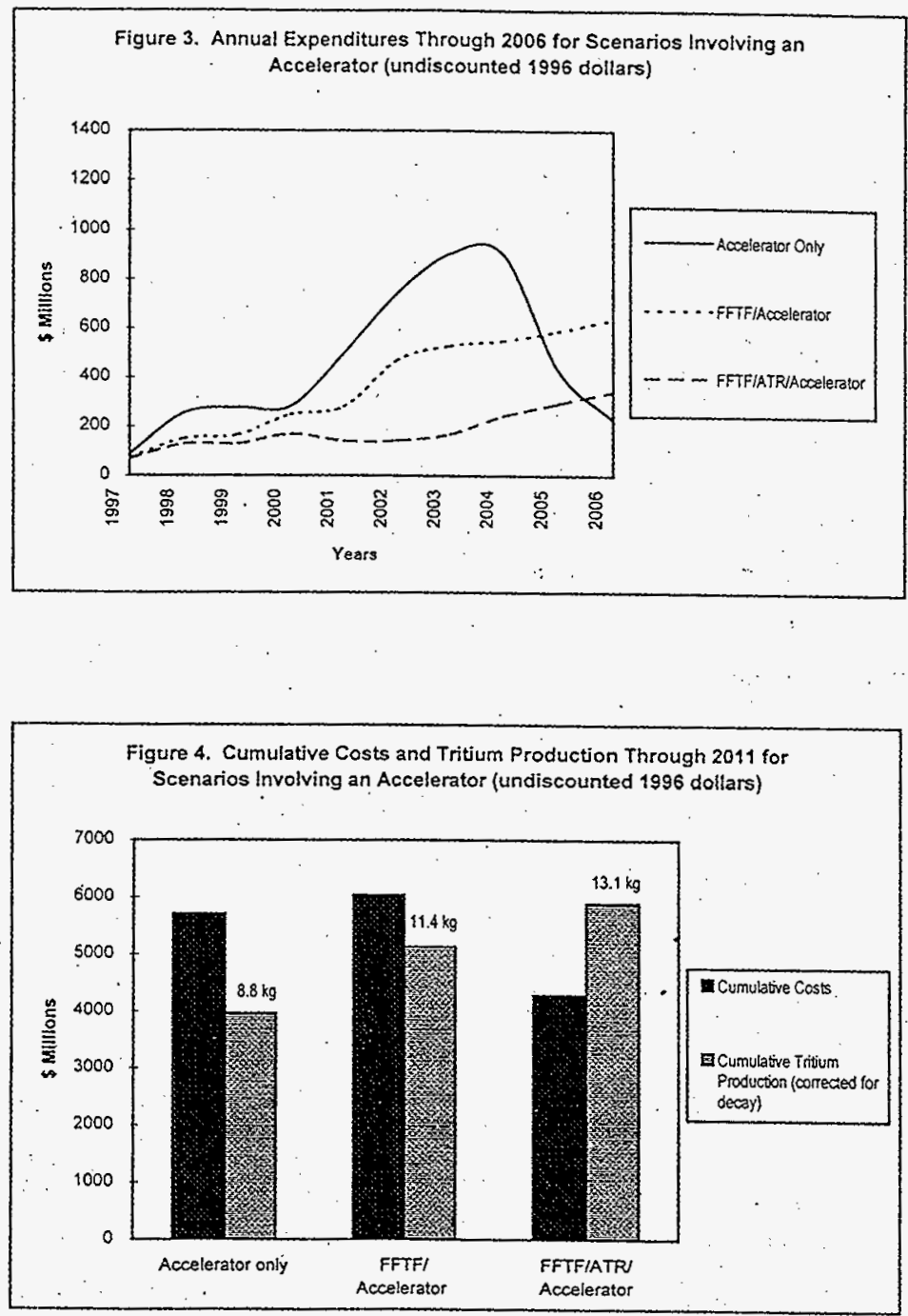


\section{Cost Advantages of an FFTF/ATR/CLWR Tritium Supply System}

Using commercial reactors as the primary tritium supply source would involve either purchasing a CLWR or purchasing irradiation services from commercial facilities. Including the FFTF and ATR in partnership with a purchased CLWR tritium source would lower the tritium production requirements of the CLWR. There is, however, no cost advantage to including the FFTF and ATR in a system based on successful purchase of irradiation services from CLWRs. In addition, adding the FFTF and ATR to a tritium production system based on a purchased CLWR does not reduce total life cycle cosis, although it does reduce the near-term costs. Nonetheless, the near-term tritium production capabilities of the FFTF and ATR would extend the time when irradiation services would be required, and the amount of tritium production required would be decreased if the FFTF continued in operation.

\section{Purchasing a Commercial Reactor}

With near-term FFTF and ATR tritium production, the peak expenditures required to purchase a commercial reactor would be pushed into the future. While the cost of a commercial reactor may vary widely depending on the time of purchase, the cost of the reactor is assumed to be constant for this analysis regardless of purchase date. As a result, while adding the FFTF and the ATR to the tritium supply system extends the commercial reactor purchase (and provides near-term budget relief), it would not reduce life cycle costs, given the assumption of a fixed cost for the reactor.

Significant near-term cost advantages would result from including the FFTF and the ATR in a CLWRbased tritium production scenario. Annual expenditures during the next ten years are shown in Figure 5 for three scenarios: (1) the purchase of a commercial reactor ("CLWR only"); (2) a combination of the FFTF and a purchased CLWR ("FFTF/CLWR"); and (3) a combination of the FFTF, the ATR, . and a purchased CLWR ("FFTF/ATR/CLWR"). (15) "Annual expendirures during the ten-year period are relatively flat at about $\$ 125$ million to $\$ 175$ million when FFTF and ATR are included, avoiding the $\$ 1.2$ billion reactor purchase peak in the 1997-2006 time period. (Annual expenditures through 2035 for these scenarios are provided in Part B of the Supplement to this paper.)

Adding the FFTF and the ATR to the CLWR purchase option provides more new tritium in the near term (through 2011) at lower near-term cumulative costs, as shown in Figure 6 . Operating the FFTF and ATR as near-term complements to a purchased CLWR would provide two reliable sources of new . tritium to meet near-term supply requirements.

\section{Purchasing Commercial lrradiation Services}

The tritium supply system based on purchased CLWR irradiation services (IS) requires the lowest expenditure levels (reaching about $\$ 140$ million in 2005) of any of the supply system scenarios evaluated. Expenditures are relatively flat at $\$ 100$ million to $\$ 160$ million when the FFTF is included, and at a slightly higher level for the FFTF/ATR/CLWR-IS scenario. No cost peaks are incurred through 2035 for any of the irradiation-service-based scenarios. Annual expenditure patterns for these scenarios are provided in Part $B$ of the Supplement to this paper.

\footnotetext{
(19) Cost comparisons are based on purchasing an existing CLWR. Cost estimates for purchasing and completing a parially built reactor are significantly greater than the estimated purchase cost of an existing reactor (see DOE/DP-0134).
} 

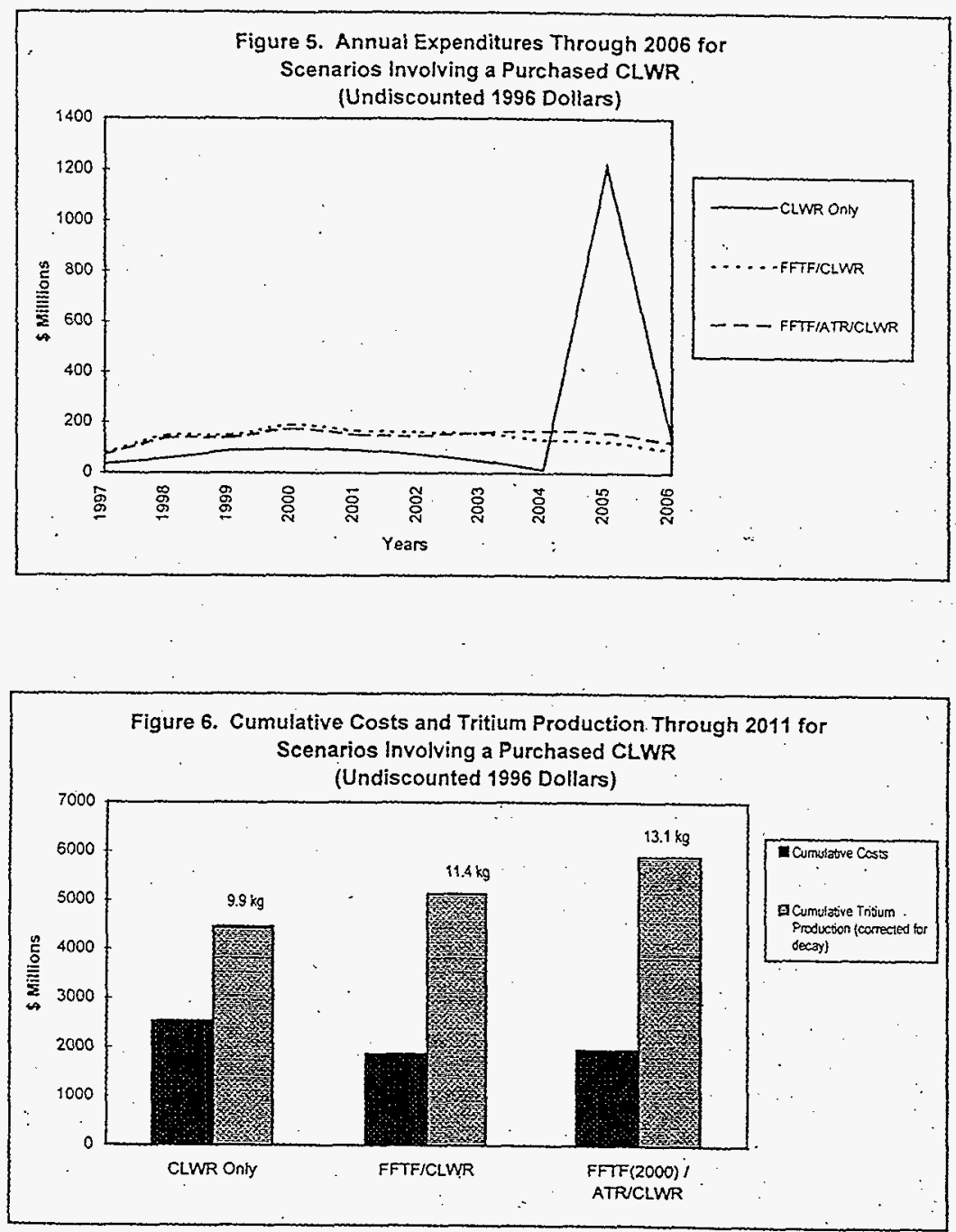


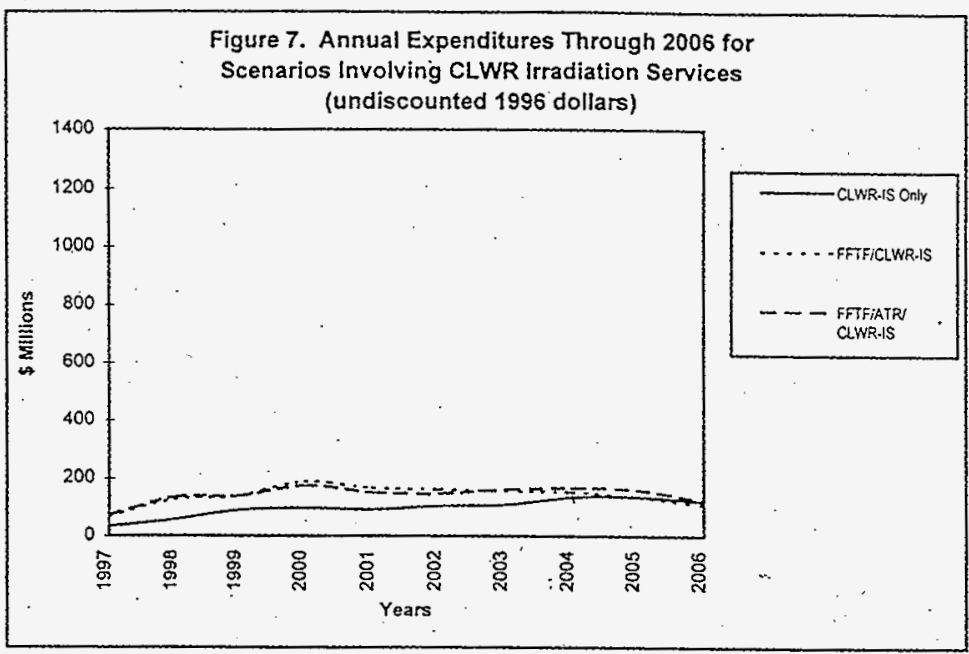

Figure 8. Cumulative Costs and Tritium Production Through 2011 for Scenarios Involving CLWR Irradiation Services

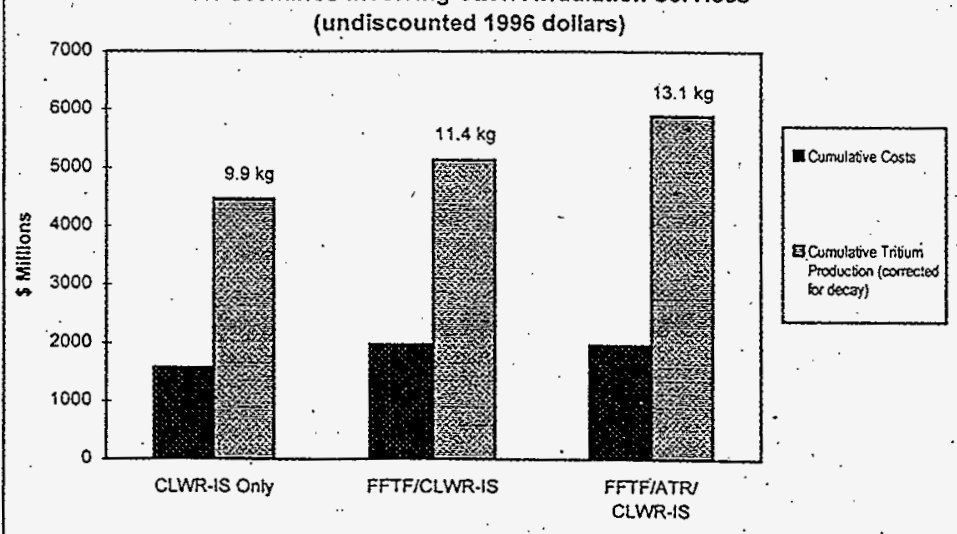


There are no evident near-term cost advantages to including the FFTF and the ATR along with commercial irradiation services in comparison with irradiation services alone, as shown in Figure 7. Annual expenditures reach about $\$ 140$ million for the CLWR-IS alone scenario, $\$ 190$ million for the FFTF/CLWR-IS scenario, and $\$ 170$ million for the FFTF/ATR/CLWR-IS scenario. The CLWR-IS alone scenario has the lowest annual expenditures of all tritium production scenarios considered.

However, as discussed in previous sections, instintional concerns with convering commercial reactors to defense use could (1) delay this option beyond 2005 , (2) result in less reliable supply in the longer term, or (3) prevent access to CLWRs aitogether.

- The near-term production capabilities of the FFTF and the ATR in the CLWR-IS scenario do provide additional new tritium at similar near-term cumulative costs when there are delays in purchasing irradiation services from commercial reactors (see Figure 8). Because the FFTF and the ATR raise different instirutional concerns than the CLWR-IS option, the FFTF/ATR/CLWR-IS scenario provides more certainty in meeting near-term tritium requirements.

\section{Scenario Life Cycle Costs}

Life cycle costs for the nine scenarios considered are given in Table 2. Life cycle costs are computed through 2030 for all scenarios. although not all tritium production sources operate for the full life cycle (e.g., the ATR). Life cycle costs through 2050 are provided in Part B of the Supplement to this paper. Assumptions regarding tritium production schedules and capacities are given in Part $A$ of the Supplement.

\begin{tabular}{|c|c|c|}
\hline \multicolumn{3}{|c|}{$\begin{array}{l}\begin{array}{c}\text { Table 2. Life Cycle Costs (Through 2030) of Tritium Production Scenario } \\
\text { (billions of 1996 dollars) }\end{array} \\
\end{array}$} \\
\hline Scenario & $\begin{array}{c}\text { Discounted } \\
\text { Cost }\end{array}$ & $\begin{array}{c}\text { Undiscounted } \\
\text { Cost }\end{array}$ \\
\hline Accelerator & 5.3 & 9.9 \\
\hline FFTF/Accelerator & 4.9 & 9.0 \\
\hline FFTF/ATR/Accelerator & $4.2^{\circ}$ & 8.7 \\
\hline \multicolumn{3}{|c|}{ 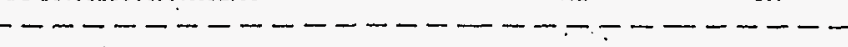 } \\
\hline CLWR purchase & 2.5 & 5.5 \\
\hline FFTF/CLWR purchase & 2.6 & 5.5. \\
\hline FFTF/ATR/CLWR purchase & 2.5 & 5.4 \\
\hline \multicolumn{3}{|c|}{ 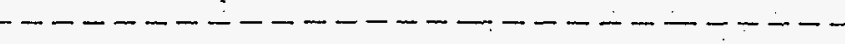 } \\
\hline CLWR irradiation services. & 1.8 & 3.9 \\
\hline FFTF/CLWR irradiation services & 2.1 & 4.3 \\
\hline FFTF/ATR/CLWR irradiation services & 2.1 . & 4.3 \\
\hline
\end{tabular}

Based on the schedule and capacity assumptions described in Part A of the Supplement, the discounted life cycle costs of the accelerator-based tritium production systems are lower when the FFTF or FFTF and ATR are included than when the accelerator is used alone. The CLWR-based systems involving purchasing a reactor cost about the same (on a discounted basis) when the FFTF or the FFTF and ATR 
are included in comparison with not including them. All CLWR-based systems are less costly than production systems involving the accelerator. Finally, using CLWR irradiation services is the least costly option and including the FFTF or ATR in an irradiation-services-based system offers no calculated cost advantages.

\section{FFTF/ATR COST ADVANTAGES: SUMMARY}

- Including the FFTF and the ATR allows the large, near-term funding requirements for the accelerator or CLWR purchase to be shifted into the future, reducing near-term expendiures.

- Life cycle costs are reduced when the FFTF and ATR are included in an accelerator-based tritium supply system.

- Schedule extensions resulting from including the FFTF and the ATR in the tritium production system could reduce design, construction, and operating costs for the accelerator.

- Adding the FFTF and ATR to the tritium supply system can provide more near-term tritium at cumulative costs lower than or similar to the costs for the accelerator-only, purchasedCLWR-only, or purchased-irradiation-services-only options. The FFTF and ATR would also. increase the reliability of tritium supply and the flexibility of the system to respond to changing requirements and conditions. 


\section{MITIGATING INSTITUTIONAL UNCERTAINTY}

Using the FFTF in a tritium production system would provide the schedule flexibility needed to resolve critical institutional issues that could delay the use of a CLWR (a purchased reactor or purchased irradiation services) and, possibly, an accelerator. Some of the instimutional advantages and uncertainties associated with various tritium production technologies are listed in Table 3.

\begin{tabular}{|c|c|c|}
\hline Technology & Advantages & Uncertainties \\
\hline FFTF & $\begin{array}{l}\text { - The FFTF is a government-owned facility on } \\
\text { secure, government-owned property. } \\
\text { - The FFTF can contribute to the disposition of } \\
\text { surplus plutonium. } \\
\text { - The Nuclear Regulatory Commission (NRC) } \\
\text { has previously reviewed FFTF safety } \\
\text { analyses, potentially providing increased } \\
\text { public confidence in safe operation. } \\
\text { - A medical isotope production mission } \\
\text { increases public support. }\end{array}$ & $\begin{array}{l}\text { There are some uncertainties in the } \\
\text { schedule for completion of activities } \\
\text { leading to startup (a site-specific EIS, } \\
\text { safety analyses, and interactions with } \\
\text { the NRC and the Defense Nuciear } \\
\text { Facilities Safery Board). } \\
\text { - The FFIF generates spent fuel with } \\
\text { high plutonium content. } \\
\text { - Concerns could arise over using excess } \\
\text { weapons plutonium to generate tritium. }\end{array}$ \\
\hline ATR & $\begin{array}{l}\text { - The ATR is a government-owned facility on } \\
\text { secure, government-owned property. } \\
\text { - The ATR is an operating facility that } \\
\text { produces medical isotopes; public support } \\
\text { should not be an issue. }\end{array}$ & $\begin{array}{l}\text { - There is some uncertainty in the } \\
\text { schedule for completing the safety } \\
\text { analysis report revisions needed to } \\
\text { increase the tritium production level } \\
\text { above } 0.2 \mathrm{~kg} / \mathrm{yr} \text {. }\end{array}$ \\
\hline CLWR & $\begin{array}{l}\text { The NRC would retain licensing authority } \\
\text { over reactors providing radiation services, } \\
\text { potentially providing increased public } \\
\text { confidence in safe operation. } \\
\text { - An existing plant purchased by DOE would } \\
\text { originally have been built and operated under } \\
\text { NRC oversight, potentially providing } \\
\text { increased public confidence in safe operation. } \\
\text { - A CLWR could potentially contribute to the } \\
\text { disposition of surplus plutonimm. }\end{array}$ & $\begin{array}{l}\text { Civilian and defense nuclear missions } \\
\text { have traditionally been kept separate. } \\
\text { - Nonproliferation concerns associated } \\
\text { with converting CLWRs to defense } \\
\text { missions could arise. } \\
\text { - Contested licensing hearings (for new or } \\
\text { amended licenses) could delay startup. } \\
\text { - Tritiumproduction in CLWRs could } \\
\text { increase spent fuel generation. } \\
\text { - Concems could arise over using excess } \\
\text { weapons plutonium to generate tritium. }\end{array}$ \\
\hline Accelerator & - An accelerator produces no spent fuel. & $\begin{array}{l}\text { The licensing authority and processes } \\
\text { for an accelerator are unclear. } \\
\text { - There are possible national and } \\
\text { international implications of adding a } \\
\text { new facility to the nuclear weapons } \\
\text { production infrastrucnure. } \\
\text { Adequate funding may not be available. }\end{array}$ \\
\hline
\end{tabular}


The FFTF and the ATR provide the opporrunity to produce tritium using existing, secure, governmentowned facilities that were built and operated to high safety standards. The FFTF also provides a way to get an early start on disposition of surplus weapons-usable plutonium. The production of medical isotopes at both the FFTF and the ATR is expected to mitigate public concern about producing tritium in these facilities.

Using the FFTF in the nation's tritium production system, alone or together with the ATR, provides additional time to resolve the critical institutional issues associated with using commercial facilities for defense-related purposes as well as any instinutional concems associated with constructing a new facility (the accelerator) to produce weapons-related materials.

\section{MATERIAL AND WASTE TRADEOFFS}

In 1994 the National Academy of Sciences concluded that surplus weapons-usable plutonium should be made "roughly as inaccessible for weapons use as the much larger and growing quantity of plutonium that exists in spent fuel from commercial reactors. "(16) Both the FFTF and a CLWR could disposition up to about 1 metric ton per year of surplus weapons-usable plutonium while producing tritium. depending on the fuel enrichment used in each reactor.

Because the FFTF was designed to operate with mixed oxide (MOX) fuel, and the FMEF was designed to fabricate MOX fuel for the FFTF, the technical barriers to using the FFTF for plutonium disposition should be low. The FFTF could start converting the high-purity, ${ }^{(17)}$ surplus weapons-usable plutonium to unusable form eight years before the other reactor options being considered for plutonium disposition. Over the anticipated 30-year life of the FFTF, 64\% of the high-purity surplus plutonium would be converted to the "spent fuel standard." ${ }^{\text {(18) }}$ Based on the Technical Summary Report for Surplus Weapons-Usable Plutonium Disposition, the estimated cost of dispositioning all surplus plutonium using a hybrid alternative (a reactor plus immobilization) is $\$ 2,130$ million. Using the FFTF to disposition $64 \%$ of the high-purity plutonium and immobilizing the remaining surplus material would reduce the total cost by about $\$ 440$ million. (See Part $C$ of the Supplement to this paper for details on these calculations.)

The FFTF also offers advantages from a waste generation perspective when it operates solely as a tritium producer or with concomitant plutonium disposition. Table 4 compares the amount of additional spent fuel and solid low-level radioactive wastes generated by the FFTF with the amounts generated by the other tritium production altematives under consideration.

(16) National Academy of Sciences, Commintee on international Security and Arms Control, Management and Disposition of Excess Weapons Plutonium, National Academy Press, Washington, DC, 1994.

(1) If a teactor option is chosen as the only plutonium disposal method, all of the (approximately) 50 metric tons of surplus weapons-usable plutonium would be converted to reactor fuel. If a combination of methods is chosen, the plutonium that is relatively clean and easier to convert to fuel (about 32.5 metric sons) would be converted to the "spent fuel standard" in a reactor, while the remainder (17.5 metric tons), which is more contaminated, would be immobilized. (U.S. Deparment of Energy, Office of Fissile Materials Disposition. Technical Summary Repon for Surplus Weapons-Usable Plutonium Disposition. DOE/MD-0003, July 17, 1996.)

(18) The $64 \%$ figure is based on an FFTF fuel plutonium enrichment consistent wish a $1.5 \mathrm{~kg} / \mathrm{yr}$ tritium production rate. More plutonium could be incotporated into FFTF fuel if the FFTF produced tritium at a higher rate, which would require a higher fuel plutonium enrichment. 
Table 4. Waste Generation Impacts of Tritium Production Alternatives ${ }^{(19)}$

\begin{tabular}{|c|c|c|c|c|c|}
\hline \multirow[b]{2}{*}{ Waste Type } & \multicolumn{3}{|c|}{ CLWR } & \multirow[b]{2}{*}{ Accelerator } & \multirow[b]{2}{*}{ FFTF } \\
\hline & $\begin{array}{c}\text { Partially } \\
\text { Complete } \\
\text { Reactor }\end{array}$ & $\begin{array}{l}\text { Operating } \\
\text { Reactor }\end{array}$ & $\begin{array}{c}\text { Irradiation } \\
\text { Services }\end{array}$ & & \\
\hline Solid low-level waste $\left(\mathrm{yd}^{3} / \mathrm{yI}\right)$ & 710 & 160 & 160 & $57-544^{(2)}$ & 55 \\
\hline Additional spent fuel $\left(\mathrm{yd}^{3} / \mathrm{yr}\right)$ & 55 & 40 & $0-40^{(0)}$ & 0 & 3.8 \\
\hline \multicolumn{6}{|c|}{$\begin{array}{l}\text { (2) The accelerator range reflects the use of helium-3 targets (the low end) versus lithium targets (the high end). } \\
\text { thre amount of additional spent fuel generated depends on the number of reactors used to produce the needed amount } \\
\text { of tritium. Spreading the production over a larger number of reactors decreases the impact at any one reactor. }\end{array}$} \\
\hline
\end{tabular}

(19) CLWR and accelerator data are taken from the Record of Decision for the Tritium Supply and Recycling

Programmatic Environmental Impact Statement. Data for the FFTF were provided by Westinghouse Hanford Curporation. CLWR dats represent the impacts above and beyond the normal impacts of ongoing reactor operations. 


\section{ACTIONS AND EXPENDITURES NEEDED TO MAINTAIN THE FFTF AND THE ATR AS NEAR-TERM TRITIUM PRODUCTION OPTIONS}

The benefits of including the FFTF and ATR in the nation's tritium production system accrue from their ability to provide tritium in the near-term. To ensure that, if selected as part of the nation's tritium production system in the revised Tritium Supply and Recycling Programmatic ROD, the FFTF could meet the desired startup date of 2000 , work must begin in January 1997 to proceed with startuprelated analyses, design activities, and FFTF restoration efforts. Activities must also be iniriated at Idaho National Engineering Laboratory to ensure that the ATR can produce tritium as soon as possible. These activities are described in Part D of the Supplement to this paper.

\section{Near-Term FFTF Costs}

The near-term actions required to maintain the FFTF as a tritium production option through December 1998 could be completed at a total cost of $\$ 43$ million in FY97 and $\$ 90$ million in FY98. If funding currently allocated, for FFTF shutdown activities can be reprogrammed to support these actions over the next two years, the net additional funding requirements would be only $\$ 11$ million in FY97 and $\$ 54$ million in FY98.

If the FFTF startup date were to shift from 2000 to 2001 because of programmatic policy decisions or technical issues (e.g., an extended fuel fabrication schedule), the FY98 costs would decline by about $\$ 20$ million. The additional year of infrastrucnure support expenses that would be incurred to maintain . the reactor's readiness to restart would increase overall startup costs by about $\$ 50$ million.

If the FFTF is selected as part of the tritium production system and restarts in 2000 , the FY99, FY00, and FY01 FFTF costs would be $\$ 90$ million, $\$ 123$ million, and $\$ 95$ million, respectively. Thereafter, annual operating costs would be about $\$ 88$ million.

\section{Near-Term ATR Costs}

The near-term actions required to maintain the ATR as a tritium production option through December 1998 could be conducted at a cost of approximately \$7 million in FY97 and \$5 million in FY98. (These costs do not include any costs at the Savannah River Site associated with extracting tritium from the targets irradiated during this time. These costs are estimated to be less than $\$ 1$ million.) The total cost in FY99 would be about $\$ 10$ million. Thereafter, annual operating costs would be about $\$ 5$ million exclusive of extraction costs.

\section{Total Near-Term Costs}

The total near-term costs to maintain the FFTF and ATR as tritium production options through December 1998 comprise both the costs listed above and the costs to prepare a supplement to the Final PEIS for Tritium Supply and Recycling and issue a revised ROD. These costs have been estimated at $\$ 2$ million to $\$ 5$ million; it is assumed here that half of these costs would be incurred in FY 97 and half in FY98. Total costs are given in Table 5. 


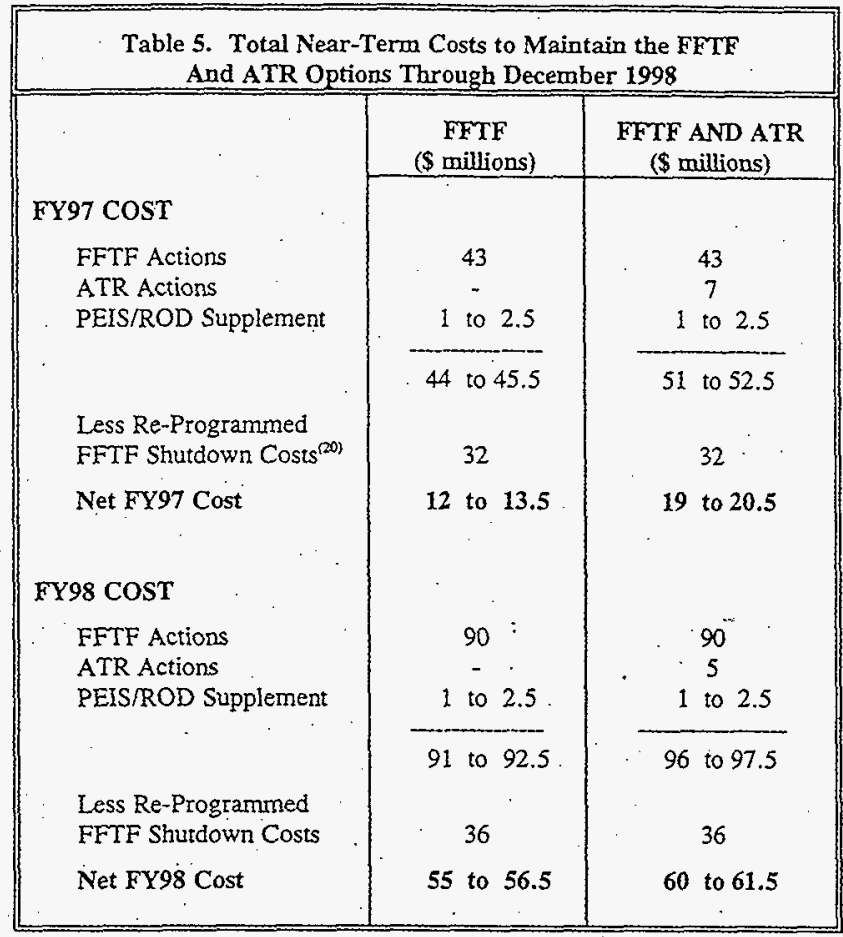

\section{CONCLUSION}

Including the FFTF and the ATR in the tritium production system provides several benefits:

(1) increased near-term production assurance over that offered by the current dual-track strategy,

(2) decreased total life cycle costs for accelerator-based tritium supply systems, (3) decreased nearterm, peak expendiures as a result of deferring costly investments, (4) the capability to get an early start on surplus plutonium disposition, and (5) a source of medical isotopes. These advantages are provided at similar or lower environmental impact (messured in terms of additional spent fuel and solid low-level radioactive waste generated) than the two options currently being developed. The FY97 and FY98 costs to include the FFTF and ATR as options through December 1998 are modest when

${ }^{120}$ The FY 97 FFTF shutdown funding value shown represents three-quarters of the anticipated FY 97 shutdown funding. 
compared with the potential discounted cost savings that would result from supplementing the accelerator-alone option with the FFTF (over $\$ 430$ million) or the FFTF and ATR (over \$I billion). ${ }^{\text {(2) }}$ On a nondiscounted basis, the potential cost savings are over $\$ 900$ million with the FFTF and about $\$ 1.1$ billion with the FFTF and ATR. In addition, excess plutonium disposition costs (undiscounted) could be reduced by $\$ 440$ million.

The FFTF and ATR cost and schedule advantages reported in this paper are conservative. In other words, the advantages of incorporating the FFTF and ATR into the nation's tritium supply system are even greater than stated here. The sources of conservatism in the analysis are reported in the text box below.

\section{SOURCES OF CONSERVATISM IN ASSESSING FFTF AND ATR ADVANTAGES}

- The maximum FFTF tritium production rate used in the analysis is $1.5 \mathrm{~kg} / \mathrm{yr}$ rather than $2 \mathrm{~kg} / \mathrm{yr}$.

- The maximum ATR tritium production rate used in the analysis is $0.2 \mathrm{~kg} / \mathrm{yr}$ rather than $0.3 \mathrm{~kg} / \mathrm{yr}$.

- Schedule benefits are assessed for both an on-time and a delayed FFTF startup.

- The capital cost reduction benefits of constructing new sources for a lower level of production than would be required without the FFTE and ATR are not included in the analysis.

- The potential absolute cost reduction benefits of constructing a new source over a longer period of time rather than on a fast-track schedule are not included in the analysis.

- The cost of developing the CLWR as a backup to the accelerator or the accelerator as a backup to the CLWR in the PEIS preferred alternative are not included in the analysis.

\footnotetext{
(21)These savings values are the discounted costs through 2030. Through 2050, adding the FFTF to the accelerator-alone option would save (on a discotinted basis) $\$ 598$ million, and adding both the FFTF and ATR to the accelerator would \$ave $\$ 1.2$ billion. (The poternial savings on a nondiscounted basis are $\$ 2.2$ billion and $\$ 2.4$ billion, tespectively.)
} 
HNF-SP. 1204

REV.O

\title{
SUPPLEMENT
}

\author{
POTENTIAL ROLE \\ OF THE \\ FAST FLUX TEST FACILITY \\ AND THE \\ ADVANCED TEST REACTOR \\ IN THE \\ U.S. TRITIUM PRODUCTION SYSTEM
}

Supplement to Policy Options White Paper

Office of Nuclear Energy, Science and Tećhnology

U.S. Department of Energy 


\section{FOREWORD}

ent to the policy options white paper, "Potential Role of the Fast Flux Test Facility and

. A-1

Test Reactor in the U.S. Tritium Production System." presents technical and cost or the white paper and provides additional details on the near-term actions that would be

aintain the Fast Flux Test Facility (FFTF) and the Advanced Test Reactor (ATR) as options through December 1998. 


\section{A. DESCRIPTION OF TRITIUM SUPPLY SYSTEM SCENARIOS}

The tritium supply system scenarios that were evaluated in this analysis, and the assumptions that were made about each tritium supply technology, are described below. Specific production rates for the accelerator and the commercial light water reactors (CLWRs) were assumed. These values, however, have no direct relationship to the production rates assumed in the Programmatic Environmental Impact Statement for Tritium Supply and Recycling (PEIS), which are expressed in terms of $3 / 16$ and $3 / 18$ of the goal quantity established by the New Production Reactors program. ${ }^{(1)}$

Nine scenarios involving the Fast Flux Test Facility (FFTF), the Advanced Test Reactor (ATR), an accelerator, a purchased CLWR, and purchased CLWR irradiation services (IS) were evaluated:

(1) Accelerator alone

(2) FFTF/Accelerator

(3) FFTF/ATR/Accelerator

(4) CLWR alone

(5) FFTF/CLWR

(6) FFTE/ATR/CLWR

(7) CLWR-IS alone

(8) FFTF/CLWR-IS

(9) FFTF/ATR/CLWR-IS.

The "accelerator alone," "CLWR alone," and "CLWR-IS alone" scenarios are derived from the PEIS preferred alternative, which would designate either an accelerator or a CLWR (a purchased CLWR or purchased irradiation services) as the primary tritium source and the other as a backup source.

The assumptions used in this analysis for each of the technologies evaluated are described below. For' each technology, tritium is assumed to be available to the stockpile one year after the commencement of tritium production, although the accelerator may be operated so that there is no such delay.

\section{ASSUMPTIONS FOR SPECIFIC TECHNOLOGIES}

\section{Accelerator}

For this analysis, the accelerator is assumed to be designed to produce $2 \mathrm{~kg} / \mathrm{yr}$ of tritium with a "sprint capability" of $3 \mathrm{~kg} / \mathrm{yr}$ ( $^{(2)}$ The earliest that an accelerator could come on line is 2007; as a result, the tritium reserves would be been drawn down below the target level between 2005 and 2007 . The accelerator must regenerate these reserves in a timely manner; hence, it would have to be built for and operated at a higher production rate than would be necessary if it did not have to regenerate reserves.

(1) The New Production Reactor program established a tritium requirement that is referred to as the "goal quantity." The Final Programmatic Environmental Impact Statement for Tritium Supply and Recycling evaluated tritium production options in terms of whether they could produce $3 / 16$ of this goal quanity annually and also whether they could produce $3 / 8$ of this quantity.

2) "Sprint capability" is the ability to begin producing tritium at a higher rate quickly and to remain at that production rate for some period of time. 
An initial accelerator production rate of $2 \mathrm{~kg} / \mathrm{yr}$, ramping up to $3 \mathrm{~kg} / \mathrm{yr}$, has been assumed for this scenario. In addition, this scenario would require the use of a helium target system, which allows tritium to be extracted continuously, eliminating the delay between initial target irradiation and the extraction of tritium from the targets. (If the accelerator is used in combination with another technology, a lower tritium production rate - e.g., a maximum of $2 \mathrm{~kg} / \mathrm{yr}$ - would suffice, and lithium targets rather than helium targets could be used.)

\section{CLWR}

A design goal for the CLWR option has not been specified. Based on the accelerator requirement, a CLWR tritium production requirement of $2 \mathrm{~kg} / \mathrm{yr}$, with a "sprint capability" of $3 \mathrm{~kg} / \mathrm{yr}$, is assumed. Three CLWR options are available:

- The DOE would purchase an operating CLWR and convert it to a defense tritium production mission.

- The DOE would purchase a partially complete CLWR and complete the construction for a defense tritium production mission.

- The DOE would contract with utilities to purchase irradiation services for DOE targets.

Because a partially complete reactor would be more costly than either of the other two CLWR options, it is not considered in detail here.

The CLWR program currently assumes that a single reactor would be purchased. However, if the Department of Energy decides to purchase irradiation services rather than a reactor, such services would have to be purchased from more than one reactor. The Nuclear Regulatory Commission has indicated that it would not find the use of a single reactor acceptable for providing irradiation services, because it might be forced to choose between safety and tritium production needs. Therefore, the CLWR program currently assumes that irradiation services would be purchased from two reactors; and that an option to purchase services from a third reactor may also be purchased.

Under the PEIS assumptions, the CLWR options that don't involve construction could come on line as early as 2003 , while a purchased reactor could come on line as early as 2004 . These schedules assume that no unplanned regulatory or institutional delays occur; the PEIS states that the CLWR would only be considered as a backup option should such delays occur. ${ }^{(3)}$ For simplicity, the analyses in this paper assume that each CLWR option comes on line in 2005.

(3) Technical Reference Repon for Tritium Supply and Recycling. U.S. Department of Energy, Office of Reconfiguration. DOE/DP+0134. October 1995. 
Three sets of assumptions about the FFTF's production profile have been made, as described below.

- The most aggressive production profile evaluated assumes that the FFTF would start up in $2000 ; 1 \mathrm{~kg} / \mathrm{yr}$ of tritium would be available to the stockpile beginning in 2001 . $^{(4)}$ The production rate would increase to $1.5 \mathrm{~kg} / \mathrm{yr}^{(5)}$ in 2003 . It is possible that the production rate could be further increased to $2 \mathrm{~kg} / \mathrm{yr}^{(6)}$ beginning in 2005 . At each production level, target and fuel tests could be conducted to support production at higher levels. The keys to meeting a 2000 date for startup include expediting all safety and environmental documentation and interactions and establishing a new fuel supply in the Fuel and Materials Examination Facility (FMEF) at Hanford by $2002 .^{\text {th }}$

- A less aggressive production profile assumes that startup could still be achieved by 2000 but that the plant would not operate above the $1.5 \mathrm{~kg} / \mathrm{yr}$ level. Under this scenario, the production rate would start out at $1 \mathrm{~kg} / \mathrm{yr}$ and would increase to $1.5 \mathrm{~kg} / \mathrm{yr}$ in 2003 and subsequently remain at or below that operating level.

- An even less aggressive production profile assumes that safery and environmental analyses together with construction of the new fuel supply would delay the facility starup until 2002. Production would stant out $1 \mathrm{~kg} / \mathrm{yr}$ and would increase to $1.5 \mathrm{~kg} / \mathrm{yr}$ in 2005 .

The analyses conducted for this paper assume that the maximum FFTF production rate is $1.5 \mathrm{~kg} / \mathrm{yr}$ and that the facility can restart in 2000 . The implications of the starup date slipping to 2002 are also assessed.

$\operatorname{ATR}^{(8)}$

The ATR is a water-cooled test reactor located at the Idaho National Engineering Laboratory. Its primary missions are to provide materials and fiels testing for the Naval Reactors program and to produce radioisotopes for medical, industrial, environmental, agricultural, and research applications. It also provides services to other govermment programs as needed. At steady-state operation, the ATR can produce more than $0.3 \mathrm{~kg} / \mathrm{yr}$ of tritium while continuing to serve its Naval Reactors mission and to produce radioisotopes.

(4) Tritium production at a rate of $1 \mathrm{~kg} / \mathrm{yr}$ would entail using the current FFTF fuel (approximately $30 \%$ enriched) together with $\mathrm{LiAlO}$, targets in the reflector region only. Tesis on more highly enriched fueis and more advanced targets would take place in the core while concurrently producing $1 \mathrm{~kg} / \mathrm{yr}$ of tritium.

(5) A production rate of $1.5 \mathrm{~kg} / \mathrm{yr}$ would entail using more highly enriched fuel - e.g., approximately $40 \%$ enriched mixed oxide (MOX) fuel - together with $\mathrm{LiAlO}_{2}$ targets in the core.

(6) While there is some uncertainty regarding the maximpm tritium production level that the FFTF could achieve, reactor physics analyses have estimated the potential production at 2 to $2.2 \mathrm{~kg} / \mathrm{yr}$. Because these higher production rates involve highly enriched (about 50\%) MOX fuel together with $\mathrm{LiO}_{2}$ targets in the core (and either $\mathrm{LiO}_{2}$ or $\mathrm{LiAlO}_{2}$ targets in the reflector), additional analysis and testing are needed to determine whether the higher production levels could be realized in practice.

(7) Available fresh and partially-irradiated FFTF fuel could provide about 1.5 years of operation, but a new fuel supply would be required after that.

(a) -Operating the Advanced Test Reactor to Support Naval Reactor Programs, Isotope Production, and Interim Tritium Production." Letter report prepared for the U.S. Department of Energy by Lockheed Martin Idaho Technologies, September 17. 1996. 
The ATR could start in 1998 on a demonstration phase that would be completed by the end of 1999; over this period, it would ramp up to its ultimate production rate. It would reach this ultimate production level in 2000 but would have produced a small amount of tritium before that time. For this analysis, a startup date of 1999 is assumed. A production rate of $0.2 \mathrm{~kg} / \mathrm{yr}$ of tritium could be achieved without revising the ATR's Safery Analysis Report (SAR). Revisions to the SAR and modifications to the reactor and its current Naval Reactors experiments would allow the ATR to increase its tritium production rate to more than $0.3 \mathrm{~kg} / \mathrm{yr}$. For this analysis, a production rate of $0.2 \mathrm{~kg} / \mathrm{yr}$ is assumed.

- The ATR would operate on an interim basis until a new tritium source - an accelerator or a CLWR comes on line; after that time, it could provide backup and surge capacity while continuing to serve its Naval Reactors mission and produce medical isotopes.

\section{DETAILED ASSUMPTIONS FOR TRITIUM PRODUCTION SCENARIOS}

\section{(1) Accelerator Alone}

The earliest that an accelerator could come on line is 2007 ; in this case, the tritium reserves would be drawn down below the desired level between 2005 and 2007 . To replenish them, it is assumed that the accelerator's tritium production rate starts at $2 \mathrm{~kg} / \mathrm{yr}$ and ramps up quickly to $3 \mathrm{~kg} / \mathrm{yr}$.

\section{(2) FFTF/Accelerator}

Under the FFTF/Accelerator scenario, the early use of the FFTF would allow the accelerator to come on line later than 2007 and to be sized to produce only (for example) $2 \mathrm{~kg} / \mathrm{yr}$. Specific assumptions are as follows:

- The FFTF would come on line in 2000 at a tritium production rate of $1 \mathrm{~kg} / \mathrm{yr}$, and would ramp up to a rate of $1.5 \mathrm{~kg} / \mathrm{yr}$ by 2003 . (In the case of delayed start, the FFTF would start producing $1 \mathrm{~kg} / \mathrm{yr}$ of tritium in 2002 and would ramp up to a rate of $1.5 \mathrm{~kg} / \mathrm{yr}$ by 2005 .)

- The accelerator would come on line in 2012 and produce tritium at a rate of, for example, $2 \mathrm{~kg} / \mathrm{yr}$.

- Once the accelerator comes on line, the FFTF could provide backup and surge capacity and continue to produce medical isotopes. For this analysis, the FFTF is assumed to cease routine tritium production after 2011 . 


\section{(3) FFTF/ATR/Accelerator}

Under this scenario, the ATR would come on line first, followed by the FFTF and the accelerator. Specific assumptions are as follows:

- The ATR would begin producing $0.2 \mathrm{~kg} / \mathrm{yr}$ beginning in 1999. The FFTF assumptions are the same as those for the FFTF/Accelerator scenario.

- The accelerator would come on line in 2016 and produce tritium at a rate of, for example. $2 \mathrm{~kg} / \mathrm{yr}$.

- Once the accelerator comes on line, the FFTF and ATR could provide backup and surge capacity and would continue to produce medical isotopes. For this analysis, the FFTF and ATR are assumed to cease routine tritium production after 2015 .

- The FFTF could continue to produce tritium after 2015 at a rate up to $1.5 \mathrm{~kg} / \mathrm{yr}$. allowing the accelerator to operate at a lower tritium production level (e.g., less than $2 \mathrm{~kg} / \mathrm{yr}$ ) and the tritium production split between the two technologies to be optimized. However, this scenario is not evaluated in this paper.

\section{(4) CLWR Alone}

Under the "CLWR alone" scenario, a purchased CLWR is assumed to begin producing tritium in 2005 : Because (in the absence of instirutional delays) the CLWR would provide new tritium beginning in 2005 , the CLWR could operate at a moderate steady state rate to maintain the tritium reserves at an acceptabie level.

\section{(5) FFTF/CLWR}

The FFTF/CLWR scenario provides additional time for the purchased CLWR to overcome institutional and regulatory hurdles to operating in a tritium production mode. Under the FFTF/CLWR scenario, the purchased CLWR could come on line later than 2005 and could be sized to produce only (for. example) $2 \mathrm{~kg} / \mathrm{yr}$. Specific assumptions are as follows:

- The FFTF assumptions are the same as those for the FFTF/accelerator scenario.

- The purchased CLWR would come on line in 2012 and produce tritium at a rate of, for example, $2 \mathrm{~kg} / \mathrm{yr}$.

- Once the purchased CLWR comes on line, the FFTF could provide backup and surge capacity and would continue to produce medical isotopes. The FFTF would cease routine tritium production after 2011 .

- Once the CLWR comes on line, the FFTF could continue to produce tritium and the production split between the FFTF and the CLWR could be optimized. For example, the FFTF could provide only backup and surge capacity, or it could continue to produce up to $1.5 \mathrm{~kg} / \mathrm{yr}$ of tritium through 2030 while the CLWR produced the remainder of the annual tritium requirement. However, this scenario is not evaluated in this paper. 


\section{(6) FFTF/ATR/CLWR}

The FFTF/ATR/CLWR scenario provides even more time for a purchased CLWR to resolve institutional and regulatory issues and to come on line. Under this scenario, the purchased CLWR would come on line in 2016 and produce tritium at a moderate rate (e.g., $2 \mathrm{~kg} / \mathrm{yr}$ rate). Specific assumptions are as follows:

- The ATR and FFTF assumptions are the same as those for the FFTF/ATR/Accelerator scenario.

- The purchased reactor would come on line in 2016 and produce tritium at a moderate rate (e.g., $2 \mathrm{~kg} / \mathrm{yr}$ ).

- Once the purchased CLWR comes on line, the FFTF and ATR could provide backup and surge capacity and would continue to produce medical isotopes. The FFTF and ATR would cease routine tritium production after 2015 .

- Once the CLWR comes on line, the production split between the FFTF and the CLWR could be optimized. However, this scenario is not evaluated in this paper.

\section{(7) CLWR-IS ALONE}

Under the "CLWR-IS alone" scenario, purchased irradiation services would begin producing tritium in 2005. Because, in the absence of instirutional delays, the CLWR would provide new tritiun in 2005 , irradiation services could produce tritium at a moderate rate (e.g., $2 \mathrm{~kg} / \mathrm{yr}$ ) to maintain the tritium reserves.

\section{(8) FFTF/CLWR-IS}

The FFTF/CLWR-IS scenario provides additional time for purchased irradiation services to overcome institutional and regulatory hurdles to operating in a tritium production mode. Under the FFTF/CLWR-IS scenario, the purchased CLWR-IS could come on line later than 2005 and could be sized at only (for example) $2 \mathrm{~kg} / \mathrm{yr}$. Specific assumptions are as follows: .

- The ATR and FFTF assumptions are the same as those for the FFTF/ATR/Accelerator scenario.

- Once the CLWR-IS comes on line, the FFTF could provide backup and surge capacity and would continue to produce medical isotopes. The FFTF would cease routine tritium production after 2011 .

- Once the CLWR-IS comes on line, the production split between the FFTF and the CLWR-IS could be optimized. However, this scenario is not evaluated in this paper. 


\section{HNF-SP- 1204}

REV.O

\section{(9) FFTF/ATR/CLWR-IS}

The FFTF/ATR/CLWR-IS scenario provides even more time for the CLWR-IS to resolve instiutional and regulatory issues and to come on line. Under this scenario, the CLWR-IS would come on line in 2016 and produce tritium at a moderate rate (e.g., $2 \mathrm{~kg} / \mathrm{yr}$ rate). Specific assumptions are as follows:

- The ATR and FFTF assumptions are the same as those for the FFTF/ATR/Accelerator scenario.

- The CLWR-1S would come on line in 2016 and produce tritium at a moderate rate (e.g.. $2 \mathrm{~kg} / \mathrm{yr}$ ).

- Once the CLWR-IS comes on line, the FFTF and ATR could provide backup and surge capacity and would continue to produce medical isotopes. The FFTF and ATR would cease routine tritium production after 2015 .

- Once the CLWR-IS comes on line, the production split between the FFTF and the CLWR-IS could be optimized. However, this scenario is not evaluated in this paper. 


\section{B. COST PROFILES FOR TRITIUM SUPPLY SCENARIOS}

The cosi assumptions and profiles for the tritium supply scenarios evaluated in this paper are described below. The assumptions used to develop the profiles are listed for each set of production scenarios: the Fast Flux Test Facility (FFTF) and the Advanced Test Reactor (ATR) used together with an accelerator, a purchased commercial light water reactor (CLWR), and purchased CLWR irradiation services (IS). Tritium production schedules and capacities are taken from the scenario descriptions in Part A. All costs are given in 1996 undiscounted dollars.

Costs are depicted in three formats:

- Annual expenditures through 2035 are displayed graphically for the FFTF/ATR/accelerator, the FFTF/ATR/CLWR, and the FFTF/ATR/CLWR-IS scenarios with the FFTF and the ATR as potential system components (Figures B-1, B-2, and B-3).

- Annual expenditures through 2035 for the FFTF/ATR/accelerator, FFTF/ATR/CLWR, and the FFTF/ATR/CLWR-IS scenarios are listed in Tables B-1, B-3, and B-5.

- Annual expenditures through 2035 for the tritium supply system components making up these scenarios are listed in Tables B-2, B-4; and B-6.

\section{Eiases for Cost Profiles}

The cost information in this Supplement was taken from several sources to develop the cost profiles for the tritium supply system components. The sources are as follows:

"Technical Reference Report for Tritium Supply and Recycling. U.S. Department of Energy, Office of Reconfiguration, DOE/DP-0134, October 1995.

- "DOE Tritium Production Options: PHB Final Report on Cost Analysis." Punam. Hayes \& Bartlett, Inc., September 1995.

- "Technical Assessment of Tritium Production Capability of the Fast Flux Test Facility." Report prepared by the U.S. Department of Energy, Defense Programs Tritium Office, March 1996.

- "Technical Assessment of Tritium Production Capability at the Fast Flux Test Facility." Draft report prepared by the U.S. Department of Energy, Office of Nuclear Energy, Science, and Technology, February 1996.

- "Tritium Production at the Fast Flux Test Facility.". Draft report prepared for the U.S. Department of Energy by Westinghouse Hanford Corporation, January 1996.

- "Operating the Advanced Test Reactor to Suppor Naval Reactor Programs, Isotope Production and Interim Tritium Production." Letter report prepared for the U.S. Department of Energy by Lockheed Martin Idaho Technologies, September 1996.

- "Fast Flux Test Facility Contribution to United States Tritium Supply Option." Letter report to the U.S. Deparment of Energy by the Pacific Northwest National Laboratory, January 1996. 
Cost estimates for startup activities for the FFTF and CLWR programs (purchase of a reactor or irradiation services) were obtained through informal discussions with individuals in Westinghouse Hanford Corporation and Pacific Northwest National Laboratory (PNNL) and with members of the independent review team commissioned by the Richland Operations Office to evaluate FFTF restart costs. Cost profiles of individual tritium production system components were then combined with schedule and production capaciry assumptions given in Part $A$ to develop cost profiles for tritium production system scenarios.

Sichedule delays for new tritium production sources (an accelerator, a CLWR. or CLWR irradiation services) were assumed to be to 2012 when the FFTF was added as a near-term tritium supply component, and to 2016 if both the FFTF and the ATR were included as near-term tritium production supply components. Additional assumptions for the cost profiles of each set of technologies assessed are given below.

\section{Tritium Supply System Scenarios Involving an Accelerator}

- Accelerator only. The accelerator-only schedule expenditure profile is based on the schedule and capacity assumptions listed in Part A. Annual cost profiles are based on the Putnam, Hayes \& Bartlett (PHB) accelerator costs for the $3 / 8$ production level. ${ }^{(9)}$ Startup costs were modified based on informal discussions with PNNL staff, and annual cost profiles were normalized to a total undiscounted 1996 dollar cost of $\$ 4.82$ billion, as listed in Nucleonics Week (May 16,1996). This total cost is similar to the PHB low-cost case for the $3 / 8$ production level.

- FFTF/Accelerator. The FFTF startup and operating costs were taken from Westinghouse Hanford Corporation FFTF cost estimates. The FFTF was assumed to produce tritium based on schedule and capacity assumptions given in Part A. The FFTF was further assumed to cease tritium production when the accelerator came on line in 2012, resulting in zero FFTF costs for tritium production starting in 2012 (i.e., the FFTF would be dedicated to producing medical isotopes).

Using the FFTF would allow the accelerator to be constructed for and operated at a lower tritium production level than would be feasible without FFTF operation. For this analysis, the capital costs of new sources are assumed to be the same regardless of required production levels; this is a conservative assumption that leads to a lower estimated cost advantage.than would result if these savings were included in the analysis. The annual accelerator operating costs used for the FFTF/Accelerator scenario are lower than those for the accelerator-anly case, reflecting (approximately) the difference between the $\mathrm{PBH} 3 / 8$ and $3 / 16$ production level cases. ${ }^{(10)}$

- FFTF/ATR/Accelerator. The ATR startup and operating costs listed in the Lockheed Martin Idaho Technologies report were used for annual ATR costs. The ATR production schedule and capacity. are based on assumptions in Part $A$. The FFTF and the ATR were assumed to cease routine tritium production in 2016 when the accelerator came on line. The accelerator operating cost assumptions for this scenario are the same as those for the FFTF/Accelerator scenario.

9) The New Production Reactor program established a tritium requirement that is referred to as the "goal quantity." The Final Programmatic Environmental Impact Statement for Tritium Supply and Recicling evaluated the accelerator and CLWR options in terms of whether they could produce $3 / 16$ of this goal quantity annually and also whether they could produce $3 / 8$ of this quantity.

.20) The annual operating cost difference is assumed to be $\$ 56$ million: about $\$ 22$ million of this is due to teduced annual electricity costs. 


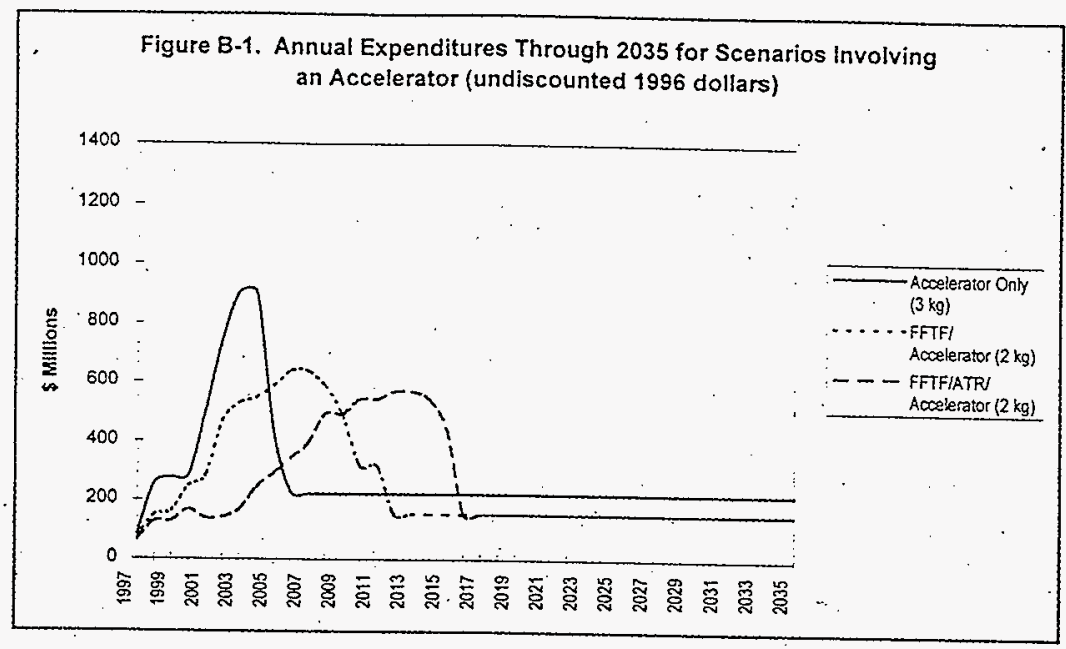




\begin{tabular}{|c|c|c|c|c|}
\hline \multicolumn{5}{|c|}{$\begin{array}{l}\text { Table B-1. Expenditure Profiles for Tritium Supply } \\
\text { Scenarios Involving an Accelerator } \\
\text { (annual expenditures; undiscounted } 1996 \$ \text { millions) }\end{array}$} \\
\hline & $\begin{array}{c}\text { Accelerator Only } \\
(3 \mathrm{~kg}) \\
\end{array}$ & $\begin{array}{c}\text { FFTF) } \\
\text { Accelerator }(2 \mathrm{~kg}\end{array}$ & & $\begin{array}{c}\text { FFTF/ATR/ } \\
\text { Accelerator }(2 \mathrm{~kg})\end{array}$ \\
\hline 1997 & 85 & 73 & & 70 \\
\hline 1998 & 255 & 150 & & 125 \\
\hline 1999 & 276 & 165 & & 130 \\
\hline 2000 & 282 & 248 & & 168 \\
\hline 2001 & 496 & 280 & & 140 \\
\hline 2002 & 739 & 468 & & 143 \\
\hline 2003 & 903 & 528 & . & 168 \\
\hline 2004 & 901 & 548 & & 243 \\
\hline 2005 & 431 & 588 & & 293 \\
\hline 2006 & 228 & 638 & & 343 \\
\hline 2007 & 221 & 638 & & 393 \\
\hline 2008 & 221 & 588 & & 493 \\
\hline 2009 & 221 & 488 & & 493 \\
\hline 2010 & 221 & 316 & & 543 \\
\hline 2011 & 221 & 316 & & 543 \\
\hline 2012 & 221 & 155 & & 568 \\
\hline 2013 & 221 & 155 & & 568 \\
\hline 2014 & 221 & 155 & & 543 \\
\hline 2015 & 221 & 155 & & 443 \\
\hline 2016 & 221 & . 155 . & & 155 \\
\hline 2017 & 221 & $155^{\circ}$ & · & 155 \\
\hline 2018 & 221 & 155 & & 155 \\
\hline 2019 & 221 & 155 & & 155 \\
\hline 2020 & 221 & $\cdot 155$ & & 155 \\
\hline 2021 & 221 & 155 & & 155 \\
\hline 2022 & 221 & 155 & & 155 \\
\hline 2023 & 221. & 155 & $\cdot \cdot$ & 155 \\
\hline 2024 & 221 & 155 & & 155 \\
\hline 2025 & 221 & 155 & - & 155 \\
\hline 2026 & 221 & 155 & & 155 \\
\hline 2027 & 221 & 155 & . & 155 \\
\hline 2028 & $\therefore 221$ & 155 & & 155 \\
\hline 2029 & 221 & 155 & & 155 \\
\hline 2030 & 221 & 155 & & 155 \\
\hline 2031 & $221^{\circ}$ & 155 & & 155 \\
\hline 2032 & 221 & 155 & $\cdot$ & $155^{\circ}$ \\
\hline 2033 & 221 & 155 & .. & 155 \\
\hline 2034 & 221 & 155 & & 155 \\
\hline 2035 & 221 & 155 & & 155 \\
\hline
\end{tabular}




\begin{tabular}{|c|c|c|c|c|c|}
\hline \multicolumn{6}{|c|}{$\begin{array}{l}\text { Table B-2. Expenditure Profiles for Components of Tritium Supply } \\
\text { System Scenarios Involving an Accelerator } \\
\text { (annual expenditures; undiscounted } 1996 \text { \$ millions) }\end{array}$} \\
\hline Year & FFTF $(2000)$ & ATR (1999) & $\begin{array}{l}\text { Accelerator } \\
(3 \mathrm{~kg}, 2007)\end{array}$ & $\begin{array}{l}\text { Accelerator } \\
(2 \mathrm{~kg}, 2012)\end{array}$ & $\begin{array}{l}\text { Accelerator } \\
(2 \mathrm{~kg}, 2016)\end{array}$ \\
\hline 1997 & 43 & 7 & 85 & 30 & 20 \\
\hline 1998 & 90 & 5 & 255 & 60 & 30 \\
\hline 1999 & 90 & 10 & 276 & 75 & 30 \\
\hline 2000 & 123 & 5 & 282 & 125 & 40 \\
\hline 2001 & 95 & 5 & 496 & 185 & 40 \\
\hline .2002 & 88 & 5 & 739 & 380 & 50 \\
\hline 2003 & 88 & 5 & 903 & 440 & 75 \\
\hline 2004 & 88 & 5 & 901. & 460 & 150 \\
\hline 2005 & 88 & 5 & 431 & 500 & 200 \\
\hline 2006 & 88 & 5 & 228 & 550 & 250 \\
\hline 2007 & 88 & 5 & 221 & 550 & 300 \\
\hline 2008 & 88 & 5 & 221 & 500 & 400 \\
\hline 2009 & 88 & 5 & 221 & 400 & 400 \\
\hline 2010 & 88 & 5 & 221 & $228 \ldots$ & 450 \\
\hline 2011 & 88 & 5 & 221 & 228 & 450 \\
\hline 2012 & 88 & 5 & 221 & 155 & 475 \\
\hline 2013 & 88 & 5 & 221 & 155 & 475 \\
\hline 2014 & 88 & 5 & $22 i$ & 155 & 450 \\
\hline 2015 & & 5 & 221 & 155 & 350 \\
\hline 2016 & 88 & 5 & 221 & 155 & 155 \\
\hline 2017 & 88 & 5 & 221 & 155 & 155 \\
\hline 2018 & 88 & $s$ & 221 & 155 & 155 \\
\hline 2019 & $88^{\circ}$ & 5 & 221 & 155 & 155 \\
\hline 2020 & 88 & 5 & 221 & 155 & 155 \\
\hline 2021 & 88 & 5 & 221 & 155 & 155 \\
\hline 2022 & 88 & 5 & 221 & 155 & 155 \\
\hline 2023 & 88 & 5 & 221 & - 155 & 155 \\
\hline 2024 & 88 & 5 & 221 & 155 & 155 \\
\hline 2025 & 88 & 5 & 221 & . 155 & 155 \\
\hline 2026 & 88 & 5 & 221 & 155 & 155 \\
\hline 2027 & 88 & 5 & 221 & 155 & 155 \\
\hline 2028 & 88 & 5 & 221 & 155 & 155 \\
\hline .2029 & 88 & 5 & 221 & 155 & 155 \\
\hline 2030 & 88 & 5 & 221 & 155 & 155 \\
\hline 2031 & 88 & 5 & 221 & 155 & 155 \\
\hline 2032 & 88 & 5 & 221 & 155 & 155 \\
\hline 2033 & 88 & 5 & 221 & 155 & 155 \\
\hline 2034 & 88 & 5 & 221 & 155 & 155 \\
\hline 2035 & 88 & 5 & 221 & 155 & 155 \\
\hline
\end{tabular}




\section{Tritium Supply System Scenarios Involving a Purchased CLWR}

- CLWR only. The schedule and capacity assumptions for the purchase of an existing reactor are listed in Part A. Anrual cost profiles are based on the PHB costs for a 3/8 production level high-cost case for a purchased reactor, where revenues from the sale of electricity are assumed to partially offset operating costs. Startup and operating cost leveis were modified from the PHB profiles based on updated information provided by PNNL staff.

- FFTF/CLWR. The FFTF starup and operating costs used for the FFTF/accelerator scenario were. used in this scenario. The FFTF was assumed to cease tritium production activities when the CLWR came on line, resulting in zero FFTF cosis for tritium production after 2011. Reactor operating costs were assumed to be the same as in the CLWR-only scenario.

- FFTF/ATR/CLWR. The ATR startup and operating costs for this scenario are the same as those

- used in the FFTF/ATR/accelerator scenario. Both the ATR and FFTF are assumed to end routine tritium production in 2016 with the purchase of the commercial reactor. 


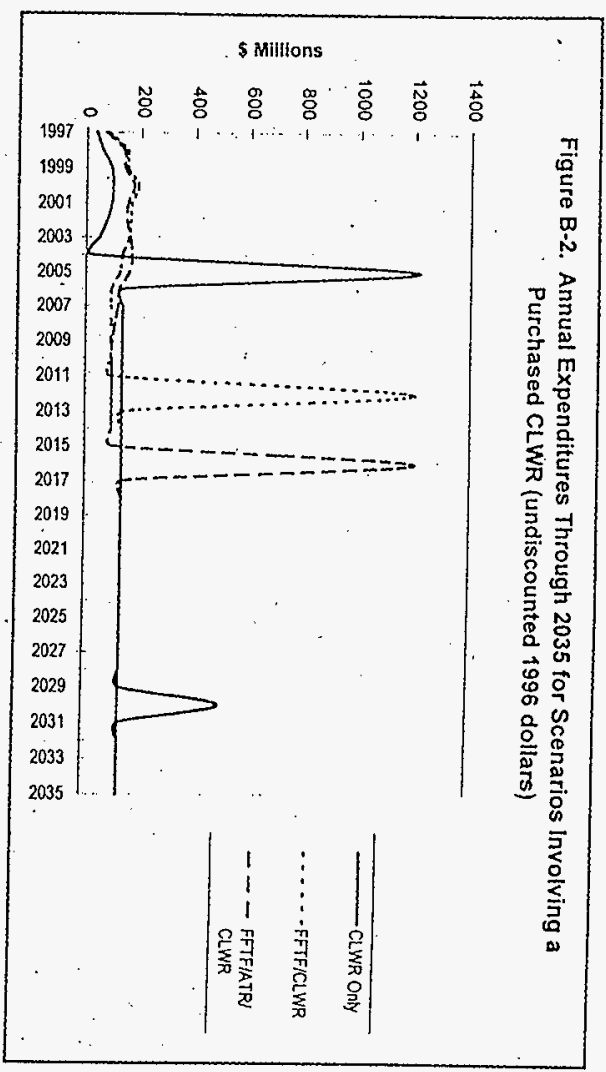

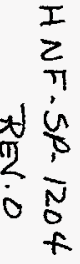


HNF-SP-1204

REV.O

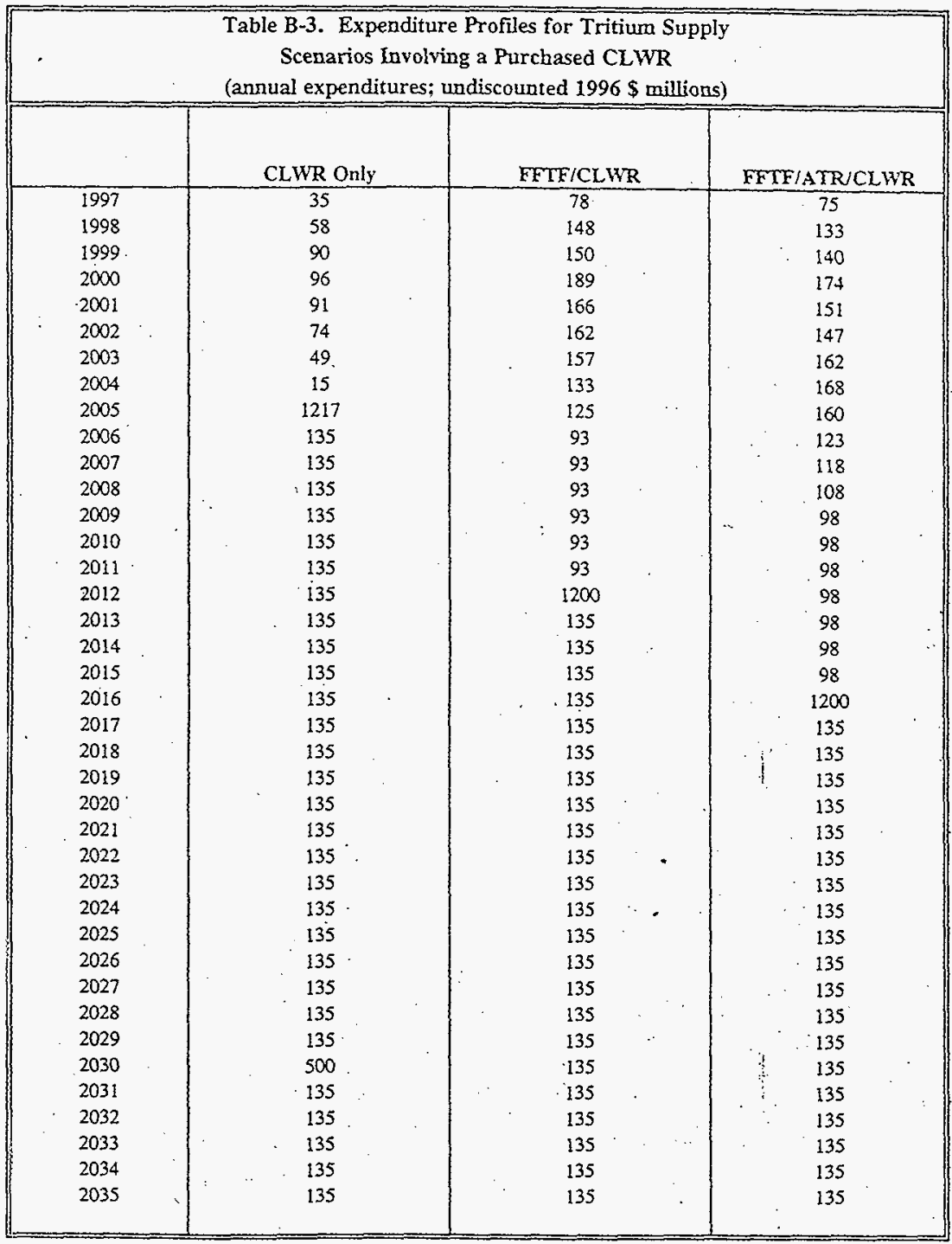

B- 8 


\begin{tabular}{|c|c|c|c|c|c|}
\hline \multicolumn{6}{|c|}{$\begin{array}{l}\text { Table B-4. Expenditure Profiles for Components of Tritium Supply } \\
\text { System Scenarios InYolving a Purchased CLWR } \\
\text { (annual expenditures; undiscounted } 1996 \text { \$ millions) }\end{array}$} \\
\hline Year & $\begin{array}{c}\text { CLWR } \\
\text { PURCHASE } \\
(2005) \\
\end{array}$ & $\begin{array}{l}\text { CLWR } \\
\text { PURCHASE } \\
(2012)\end{array}$ & $\begin{array}{l}\text { CLWR } \\
\text { PURCHASE } \\
(2016) \\
\end{array}$ & FFTF $(2000)$ & ATR (1999) \\
\hline 1997 & 35 & 35 & 25 & 43 & 7 \\
\hline 1998 & 58 & 58 & 38 & $\infty$ & 5 \\
\hline 1999 & 90 & 60 & .40 & 90 & 10 \\
\hline 2000 & 96 & 66 & 46 & 123 & 5 \\
\hline 2001 & 91 , & 71 & 51 & 95 & 5 \\
\hline 2002 & 74 & 74 & 54 & 88 & 5 \\
\hline 2003 & 49 & 69 & 69 & 88 & 5 \\
\hline 2004 & 15 & 45 & 75 & 88 & 5 \\
\hline 2005 & 1217 & 37 & 67 & 88 & 5 \\
\hline 2006 & 135 & 5 & 30 & 88 & 5 \\
\hline 2007 & 135 & 5 & 25 & 88 & 5 \\
\hline 2008 & 135 & 5 & 15 & 88 & 5 \\
\hline 2009 & 135 & 5 & $:^{5}$ & $88 \ldots$ & 5 \\
\hline 2010 & 135 & 5 & 5 & 88 & 5 \\
\hline 2011 & 135 & 5 & 5 & 88 & 5 \\
\hline 2012 & 135 & 1200 & 5 & 88 & 5 \\
\hline 2013 & 135 & 135 & 5 & 88 & 5 \\
\hline 2014 & 135 & 135 & 5 & 88 & 5 \\
\hline 2015 & 135 & 135 & 5 & 88 & 5 \\
\hline 2016 & 135 & 135 & 1200 & 88 & 5 \\
\hline 2017 & 135 & $135^{\circ}$ & 135 & 88 & 5 \\
\hline 2018 & 135 & 135 & 135 & 88 & 5 \\
\hline 2019 & 135 & 135 & 135 & 88 & 5 \\
\hline 2020 & 135 & 135 & 135 & 88 & 5 \\
\hline 2021 & 135 & 135 & 135 & 88 & 5 \\
\hline 2022 & 135 & 135 & $135^{\circ}$ & 88 & 5 \\
\hline 2023 & 135 & 135 & 135 & 88 & 5 \\
\hline $2024^{\circ}$ & 135 & 135 & 135 & 88 & 5 \\
\hline 2025 & 135 & 135 & 135 & 88 & 5 \\
\hline 2026 . & 135 & 135 & 135 & 88 & 5 \\
\hline 2027 & 135 & 135 & 135 & 88 & 5 \\
\hline 2028 & 135 & 135 & 135 & 88 & 5 \\
\hline 2029 & 135. & 135 & 135 & 88 & 5 \\
\hline 2030 & 500 & 135 & 135 & 88 & 5 \\
\hline 2031 & 135 & 135 & 135 & 88 & 5 \\
\hline 2032 & 135 & 135 & 135 & 88 & 5 \\
\hline 2033 & 135 & 135 & 135 & 88 & 5 \\
\hline 2034 & 135 & 135 & 135 & 88 & 5 \\
\hline 2035 & 135 & $13 \dot{5}$ & 135 & 88 & 5 \\
\hline
\end{tabular}




\section{Tritium Supply System Scenarios Involving Purchased CLWR Irradiation Services}

- CLWR-Irradiation Services (IS) Only. Schedule and commercial reactor irradiation capaciry are taken from assumptions given in Part A. Annual cost profiles are based on PHB costs for a $3 / 8$ production level low-cost case for purchased. irradiation services. Starrup costs and operations costs were modified based on updated information oblained from PNNL staff.

- FFTF/CLWR-IS. The FFTF starup and operating costs for this scenario are the same as those used for the FFTF/accelerator scenario. The FFTF was assumed to cease routine tritium production in . 2012 when commercial irradiation services are obtained. The costs of commercial irradiation services were assumed to be the same as the CLWR-IS-only scenario.

- FFTF/ATR/CLWR-IS. The ATR startup and operating cosis were taken from the FFTF/ATR/accelerator scenario. The FFTF and ATR were assumed to cease tritium production in 2016 when commercial irradiation services are obtained. The costs of commercial irradiation services were assumed to be the same as in the CLWR-IS-only scenario. 
. Figure B-3. Annual Expenditures Through 2035 for Scenarios Involving CLWR Irradiation Services (undiscounted 1996 dollars)

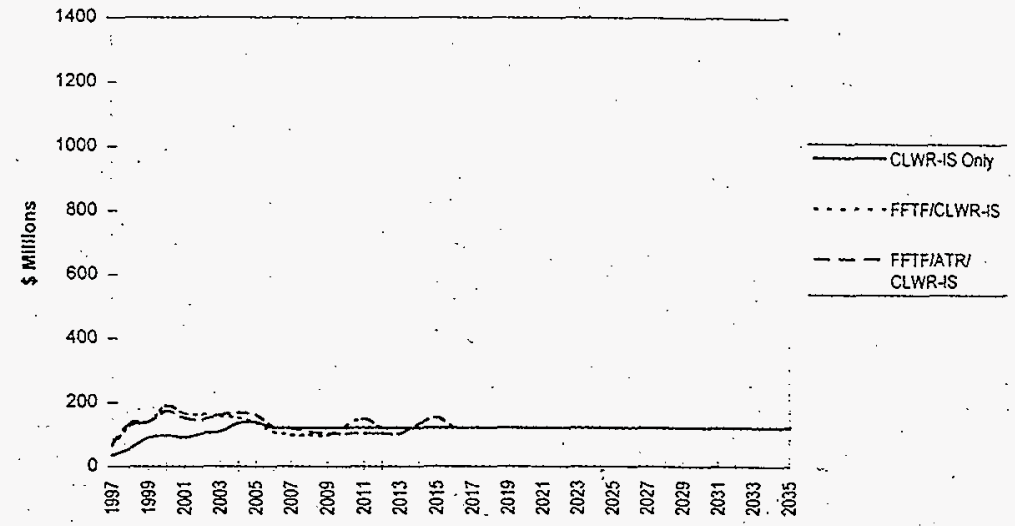


HNF-SP-1204

ReV.O

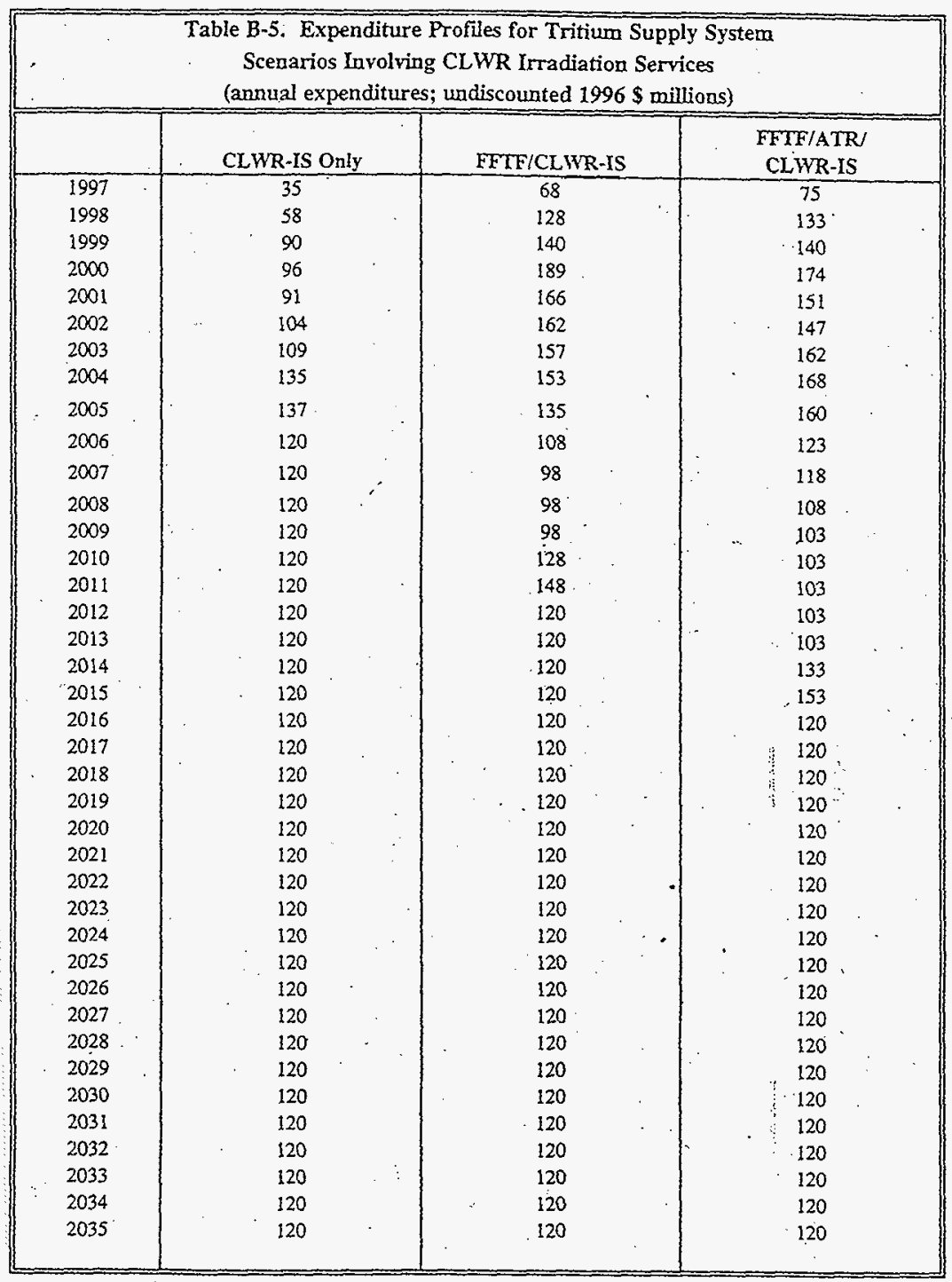




\begin{tabular}{|c|c|c|c|c|c|c|}
\hline \multicolumn{7}{|c|}{$\begin{array}{l}\text { Table B-6. Expenditure Profiles for Components of Tritium Supply } \\
\text { System Scenarios Involving CLWR Irradiation Services } \\
\text { (annual expenditures; undiscounted } 1996 \$ \text { millions) }\end{array}$} \\
\hline Year & $\begin{array}{c}\text { CLWR-IS } \\
(2005) \\
\end{array}$ & $\begin{array}{c}\text { CLWR-IS } \\
\text { (2012) } \\
\end{array}$ & $\begin{array}{c}\text { CLWR-IS } \\
(2010) \\
\end{array}$ & EFTF $(2000)$ & ATR (1999) & \\
\hline 1997 & 35 & 25 & 25 & 43 & 7 & \\
\hline 1998 & 58 & 38. & 38 & 90 & 5 & \\
\hline 1999 & 90 & 50 & 40 & 90 & 10 & \\
\hline 2000 & 96 & 66 & 46 & 123 & 5. & \\
\hline 2001 & 91 & 71 & 51 & 95 & 5 & \\
\hline 2002 & 104 & 74 & 54 & .88 & 5 & \\
\hline 2003 & 109 & 69 & 69 & 88 & 5 & \\
\hline 2004 & 135 & 65 & 75 & 88 & 5 & \\
\hline 2005 & 137 & 47 & 67 & 88 & 5 & \\
\hline 2006 & 120 & 20 & 30 & 88 & 5 & \\
\hline 2007 & 120. & 10 & 25 & 88 & 5 & \\
\hline 2008 & 120 & 10 & 15 & 88 & 5 & \\
\hline 2009 & 120 & 10 & 10 & $88 \ldots$ & 5 & \\
\hline 2010 & 120 & 40 & 10 & 88 & 5 & \\
\hline 2011 & 120 & 60 & 10 & 88 & $s$ & \\
\hline 2012 & 120 & 120 & 10 & 88 & 5 & \\
\hline 2013 & 120 & 120 & 10 & .88 & 5 & \\
\hline 2014 & 120 & 120 & 40. & 88 & 5 & \\
\hline 2015 & 120 & 120 & 60 & 88 & 5 & \\
\hline 2016 & 120 & 120 & 120 & 88 & 5 & \\
\hline 2017 & $120^{\circ}$ & 120 & $120^{\circ}$ & 88. & 5 & \\
\hline $2018^{\circ}$ & 120 & 120 & 120 & 88 & 5 & \\
\hline 2019 & 120 & 120 & 120 & 88 & 5 & \\
\hline 2020 & 120 & 120 & 120 & 88 & $5^{\circ}$ & \\
\hline 2021 & 120 & 120 & 120 & 88 & 5 & \\
\hline 2022 & 120 & 120 & 120 & 88 & 5 & \\
\hline 2023 & 120 & 120 & 120 & 88 & 5 & \\
\hline 2024 & 120 & 120 & 120 & 88 & 5 & \\
\hline 2025 & 120 & 120 & 120 & 88 & 5 & \\
\hline 2026 & 120. & 120 & 120 & 88 & 5 & \\
\hline 2027 & 120 & 120 & 120 & 88 & 5 & \\
\hline 2028 & 120 & 120 & 120 & 88 & 5 & \\
\hline 2029 & 120 & 120. & 120 & 88 & 5. & \\
\hline $2030^{\circ}$ & 120 & 120 & 120 & 88 & 5 & \\
\hline 2031 & 120 & 120 & $.120^{\circ}$ & 88 & 5 & \\
\hline 2032 & 120 & 120 & .120 & 88 & 5 & \\
\hline 2033 & 120 & 120 & 120 & 88 & 5 & \\
\hline 2034 & 120 & 120 & 120 & 88 & 5 & \\
\hline 2035 & 120 & 120 & 120 & 88 & 5 & \\
\hline
\end{tabular}


Table B-7 presents the discounted life-cycle costs for all scenarios through 2050. (The Programmatic Environmental Impact for Tritium Supply and Recycling computed life cycle costs over about this same time-frame.)

\begin{tabular}{|lcc|}
\hline \multicolumn{2}{|c|}{$\begin{array}{c}\text { Table B-7. Life Cycle Costs (Through 2050) of Tritium Production Scenarios } \\
\text { (billions of 1996 dollars) }\end{array}$} \\
\hline Scenario & $\begin{array}{c}\text { Discounted } \\
\text { Cost }\end{array}$ & $\begin{array}{c}\text { Undiscounted } \\
\text { Coss }\end{array}$ \\
Accelerator & & \\
FFTF/Accelerator & 5.9 & 14.3 \\
FFTF/ATR/Accelerator & 5.2 & 12.1 \\
CLWR Purchase & 4.6 & 11.8 \\
FFTF/CLWR Purchase & 2.9 & 8.2 \\
FFTF/ATR/CLWR Purchase & 3.0 & 8.6 \\
CLWR irradiation services & 2.9 & 6.5 \\
FFTF/CLWR irradiation services & 2.1 & 6.3 \\
FFTF/ATR/CLWR irradiation services & 2.4 & 6.7 \\
\hline
\end{tabular}




\section{CALCULATION OF POTENTIAL SAVINGS FROM USING THE FFTF IN THE DISPOSITION OF SURPLUS PLUTONIUM}

Disposition of surplus weapons-usable plutonium is being considered in the Environmental Impact Statement for Surplus Weapons-Usable Plutonium Disposition (EIS). Based on the Technical Summary Report for that EIS, if a reactor were chosen as the only plutonium disposition method, all of the (approximately) 50 metric tons (MT) of surplus weapons-usable plutonium would be converted to reactor fuel. If a combination of methods (the hybrid method) is chosen, the plutonium that is relatively clean and easier to convert to fuel (about $32.5 \mathrm{MT}$ ) would be used in a reactor, while the remainder $(17.5 \mathrm{MT})$, which is more contaminated, would be immobilized (e.g., in a glass or ceramic matrix) and placed in a repository. ${ }^{\text {(it) }}$

The estimated cost of dispositioning all surplus plutonium using the reactor/immobilization hybrid method is $\$ 2.13$ billion. This includes the cost to fabricate mixed-oxide (MOX) fuel for use in a light water reactor. Since the Fast Flux Test Facility (FFTF) was designed to bum MOX fuel, it represents a unique opportunity to disposition a significant fraction of the surplus plutonium while producing tritium and medical isotopes.

If the FFTF were used to disposition plutonium, the MOX fuel for the FFTF would be fabricated in the Fuel and Materials Examination Facility (FMEF) on the Hanford Site. Assuming that the Department of Energy would not construct a separate light water reactor fuel line to use the remaining plutonium, a cost savings of about $\$ 440$ million could be realized. The methodology used to calculate this estimated savings is described below. (All costs are given in constant 1996 dollars.)

The calculation assumes that the FFTF could disposition $64 \%$ of the high-purity surplus plutonium (or 20.8 MT). A higher fraction of this material (up to $25.6 \mathrm{MT}$ ) could be used in the FFTF if the plutonium enrichment of the FFTF were increased beyond that needed to produce $1.5 \mathrm{~kg} / \mathrm{yr}$ of tritium. Because the analysis in this paper assumes a $1.5 \mathrm{~kg} / \mathrm{yr}$ tritium production rate, it is assumed that only. $20.8 \mathrm{MT}$ of the surplus weapons-usable plutonium would be incorporated into FFTF fuel.

\section{Total Cost for the Hybrid Option}

The total cost to disposition the $32.5 \mathrm{MT}$ of high-purity plutonium using a light water reactor and the remainder using immobilization and placement in a repository is shown in Table $\mathrm{C}-1$.

(3s U.S. Department of Energy, Office of Fissile Materials Disposition, Technical Summary Repon for Surplies WeaponsUsable Plutonium Disposition. DOE/MD-0003. July 17.1996. 


\begin{tabular}{|l|r|r|r|}
\hline \multicolumn{3}{|c|}{$\begin{array}{c}\text { Table C-1. Cost to Disposition High-Purity Surplus Plutonium } \\
\text { Using the Reactor/Immobilization Hybrid Option }\end{array}$} \\
\hline Cost Category & Capital Cost & Operating Cost & Sum \\
\hline Front End Processing & $\$ 340 \mathrm{M}$ & $\$ 980 \mathrm{M}$ & $\$ 1,320 \mathrm{M}$ \\
\hline MOX Light Water Reactor Fuel Fabrication & $\$ 350 \mathrm{M}$ & $\$ 790 \mathrm{M}$ & $\$ 1.140 \mathrm{M}$ \\
\hline $\begin{array}{l}\text { Incremental Operational Costs Less } \\
\text { Plutonium Fuel Displacement Credit }\end{array}$ & & & \\
\hline Immobilization Costs & $\$ 210 \mathrm{M}$ & $-\$ 850 \mathrm{M}$ & $-\$ 640 \mathrm{M}$ \\
\hline Repository Costs & $\$ 220 \mathrm{M}$ & $\$ 60 \mathrm{M}$ & $\$ 280 \mathrm{M}$ \\
\hline Total Cost for the Reactor/Immobilization Hybrid Option & $0 \mathrm{M}$ & $\$ 30 \mathrm{M}$ & $\$ 30 \mathrm{M}$ \\
\hline
\end{tabular}

\section{Cost to Use the FFTF and FMEF in the Hybrid Option}

Under this option, 20.8 metric tons of surplus weapons-usable plutonium would be incorporated into FFTF fuel, with the remainder of the high-purity plutonium (11.7 metric tons) combined with the contaminated plutonium, immobilized, and placed in a repository. The estimated costs for front end processing are assumed to be the same as those for the reactor/immobilization hybrid option.

The FMEF fuel fabrication costs and the operational costs for FFTF tritium production are included in the tritium production cost estimates and are therefore not included as part of this cost estimate. The costs for immobilization of the additional plutonium are based on the unit costs ( $\$ / M T)$ used in the hybrid option above. The total cost to use the FFTF and FMEF in the hybrid option is shown in Table c-2.

\begin{tabular}{|l|r|r|r|}
\hline \multicolumn{3}{|c|}{$\begin{array}{c}\text { Table C-2. Cost to Disposition High-Purity Surplus Plutonium } \\
\text { Using the FFTF/FMEF/Imonobilization Option }\end{array}$} \\
\hline FFTF/FMEF Option Cost Category & Capital Cost & Operating Cost & Sum \\
\hline Front End Processing & $\$ 340 \mathrm{M}$ & $\$ 980 \mathrm{M}$ & $\$ 1,320 \mathrm{M}$ \\
\hline Mixed-Oxide FFTF Fuel Fabrication & $\$ 0 \mathrm{M}$ & $\$ 0 \mathrm{M}$ & $\$ 5 \mathrm{M}$ \\
\hline Incremental Operational Costs & $\$ 0 \mathrm{M}$ & $\$ 0 \mathrm{M}$ & $\$ 0 \mathrm{M}$ \\
\hline Immobilization Costs & $\$ 20 \mathrm{M}$ & $\$ 100 \mathrm{M}$ & $\$ 320 \mathrm{M}$ \\
\hline Repository Costs & & $\$ 50 \mathrm{M}$ & $\$ 50 \mathrm{M}$ \\
\hline Total Cost for the FFTF/FMEF/Immobilization Option & & $\$ 1,690 \mathrm{M}$ \\
\hline
\end{tabular}

Use of the FFTF and FMEF to disposition excess weapons-usable plutonium could save $\$ 440$ million compared with the hybrid light water reactor/immobilization alternative. 


\section{NEAR-TERM ACTIONS NEEDED TO MAINTAIN THE FFTF AND ATR AS NEAR-TERM TRITIUM PRODUCTION OPTIONS}

The actions listed below must be taken between January 1997 and December 1998 to ensure that the Fast Flux Test Facility (FFTF) and the Advanced Test Reactor (ATR) can produce tritium at the earliest possible date, thereby optimizing the benefits of incorporating these two reactors into the nation's tritium supply system.

\section{FFTF ACTIONS}

- Site-Specific National Environmental Policy Act (NEPA) Requirements. Complete a combined, site-specific EIS for the FFTF and the Fuel and Materials Examination Facility (FMEF) in time to allow construction work on the FMEF to begin immediately after the programmatic ROD is issued.

- Safety Analysis Reports. Revise the safety analysis for reflector target loading and the existing fuel; initiate and substantially complete the safety analysis for the FMEF.

- Plant Recovery. Initiate plant system restorations and conceptual design of plant upgrades. (Following the ROD, complete the purchase and installation of upgrades.)

- Targets and Target Line. Complete conceprual and advanced conceptual design of the targets and target line. (Following the ROD, complete detailed design and initiate the purchase and construction of targets and target lines.) Initiate design of advanced targets for production ramp-up.

- Fuel Supply. Complete concepual and advanced conceptual design of fuel assemblies and fuel line. (Following the ROD, complete detailed design and initiate purchase and construction of the fuel line.) Initiate design of advanced fuel for production ramp-up.

\section{ATR ACTIONS}

3he ATR can embark immediately on a demonstration phase of activities that will culminate in sustained production of $0.2 \mathrm{~kg} / \mathrm{yr}$ of tritium. This demonstration phase could take up to 3 years, depending on when NEPA documentation is complete; however, during this time, annual production will ramp up to the sustained production level. During the demonstration phase, tritium would be produced and extracted.

Some activities must be initiated immediately to ensure that the ATR can reach a production level of $0.2 \mathrm{~kg} / \mathrm{yr}$ as quickly as possible. These activities are as follows:

- Target Development and Acquisition. Develop and acquire targets for both the demonstration and production phases.

- Reconfiguration of Reactor Positions. Initiate changes to the reactor core loading for tritium production, including a gradual transition from borated fuel to nonborated fuel. Design, analyze, and purchase target holders. Conduct thermal and neutronic analyses. If necessary, initiate modifications to plant safety systems (such as filtered ventilation and control room isolation). 
- Reactor Performance Demonstrations. Initiate target performance tests in reactor positions that have not yet been tested.

- Site-Specific NEPA Requirements for the Production Phase. Complete a substantial portion of the site-specific NEPA requirements for the production phase. An Environmental Assessment would be initiated; if necessary, this work could be expanded into an Environmental Impact Statement.

- Safety Analysis Report Revision. Complete a substantial portion of the analyses and other work needed to amend the Safety Analysis Report: 